\title{
The Biology of Prostaglandins and Their Role as a Target for Allergic Airway Disease Therapy
}

\author{
Kijeong Lee, Sang Hag Lee and Tae Hoon Kim* \\ Department of Otorhinolaryngology-Head \& Neck Surgery, College of Medicine, Korea University, Seoul 02841, \\ Korea; peppermint_1111@hotmail.com (K.L.); sanghag@kumc.or.kr (S.H.L.) \\ * Correspondence: doctorthk@gmail.com; Tel.: +82-02-920-5486
}

Received: 23 January 2020; Accepted: 5 March 2020; Published: 8 March 2020

\begin{abstract}
Prostaglandins (PGs) are a family of lipid compounds that are derived from arachidonic acid via the cyclooxygenase pathway, and consist of $\mathrm{PGD}_{2}, \mathrm{PGI}_{2}, \mathrm{PGE}_{2}, \mathrm{PGF}_{2}$, and thromboxane $\mathrm{B}_{2}$. PGs signal through G-protein coupled receptors, and individual PGs affect allergic inflammation through different mechanisms according to the receptors with which they are associated. In this review article, we have focused on the metabolism of the cyclooxygenase pathway, and the distinct biological effect of each PG type on various cell types involved in allergic airway diseases, including asthma, allergic rhinitis, nasal polyposis, and aspirin-exacerbated respiratory disease.
\end{abstract}

Keywords: prostaglandins; allergy; asthma; allergic rhinitis; $\mathrm{AERD} ; \mathrm{PGD}_{2} ; \mathrm{PGE}_{2}$

\section{Introduction}

Prostaglandins (PGs) are lipid mediators, generated from arachidonic acid (AA) metabolism via cyclooxygenases (COX). They were discovered in the 1930s as regulators of blood pressure and smooth muscle contraction [1]. The distribution of synthases and receptors for each PG is different in various cell types, and PGs are activated via either paracrine or autocrine signaling on the surface of each cell type [2]. PGs bridge the interactions between various immune-modulating cells, and are considered key players in regulating pro-inflammatory and anti-inflammatory responses [3]. The role of PGs in allergic disease was first introduced in an article published in 1969, which reported the release of $\mathrm{PGE}_{2}$ and $\mathrm{PGF}_{2 \alpha}$ during anaphylaxis in an animal model [4]. Since then, numerous studies have reported on the role of PGs in allergic diseases, and technologies have been developed to produce stable analogs and generate genetically engineered animal models [5].

Allergic reactions are characterized as immunoglobulin E ( $\operatorname{IgE}$ )-dependent mechanisms, orchestrated by various cellular components and resulting in antigen-induced type 2 inflammation. Allergic diseases in the upper and lower airways include asthma, allergic rhinitis, and nasal polyposis. In airway allergic reactions, antigens that have penetrated epithelial layers are engulfed by dendritic cells (DCs), inducing them to mature and migrate to the lymph nodes, where they activate naïve $\mathrm{T}$ cells into effecter T helper 2 (Th2) cells [6]. Cytokines such as interleukin-4 (IL-4), IL-5, and IL-13 are released from Th2 cells or type 2 innate lymphoid (ILC2) cells. These cytokines, as well as epithelial-derived cytokines such as thymic stromal lymphopoietin (TSLP) and IL-33, activate the mast cells, eosinophils, and other structural cells, including smooth muscle cells and fibroblasts. These cells can also interact with each other to induce hyperreactivity [7]. Although aspirin-exacerbated respiratory disease (AERD) is not induced by the IgE-mediated hypersensitivity reaction, it is characterized by asthma, eosinophilic nasal polyposis, and nonsteroidal anti-inflammatory drug (NSAID) sensitivity, and it is a serious airway disease that affects both the upper and the lower airways [8]. AERD is dominantly regulated by lipid mediators such as PGs and leukotrienes (LTs) because the disease pathogenesis is characterized by alteration of AA metabolism $[9,10]$. 
Although PGs and their role in allergic reactions have been known about for a long time, the development of novel drugs targeting their signaling and metabolism is currently in progress, and clinical studies applying these to allergic airway diseases are being undertaken. In this review, we will discuss the potential of PGs to serve as therapeutic targets in allergic airway inflammation of the upper and lower airways. Based on an introduction of the pathways of PG generation, and the mechanisms of individual PGs in important cellular allergic reactions, we will present the regulation of PGs in clinical settings and the effects of pharmacological agents that modulate PG activation in various airway diseases such as asthma, allergic rhinitis, AERD, and nasal polyposis.

\section{Biosynthesis of Prostaglandins}

\subsection{Phospholipase $A_{2}$ and Arachidonic Acid}

All PGs and LTs derived from AA are called "eicosanoids," following the Greek word "eikosi," meaning "20," referring to the number of carbon atoms in AA. Free fatty acids, including AA, are obtained from the hydrolysis of fatty acids by phospholipase $\mathrm{A}_{2}\left(\mathrm{PLA}_{2}\right)$ at the sn-2 position of membrane phospholipids [11]. PLA $A_{2}$ enzymes are classified into six major groups: secretory PLA (sPLA $\left._{2}\right)$, cytosolic $\mathrm{PLA}_{2}\left(\mathrm{cPLA}_{2}\right), \mathrm{Ca}^{2+}$ dependent $\mathrm{PLA}_{2}\left(\mathrm{iPLA}_{2}\right)$, platelet-activating factor acetylhydrolases (PAF-AH), lysosomal PLA 2 , and adipose-specific PLA 2 [12]. In addition, based on their catalytic mechanisms, functions, and structures, they are further categorized into 16 groups. Among them, groups IIA/V/X of the sPLA 2 group, group IVA of $\mathrm{cPLA}_{2}$, and group VI of $\mathrm{PLAA}_{2}$ lead to AA production by hydrolyzing membrane phospholipids, which are then metabolized sequentially to produce PGs and LTs [13].

\subsection{The Cyclooxygenase Pathway}

PGs are derived from the COX pathway [14]. COX catalyzes the initial reaction in the generation of $\mathrm{PGG}_{2}$ by inserting two oxygen molecules into AA (Figure 1). Thereafter, sequential peroxidase reactions transform $\mathrm{PGG}_{2}$ into $\mathrm{PGH}_{2}$, the precursor for $\mathrm{PGD}_{2}, \mathrm{PGE}_{2}, \mathrm{PGF}_{2 \alpha}, \mathrm{PGI}_{2}$, and thromboxane $\mathrm{A}_{2}\left(\mathrm{TXA}_{2}\right)[14]$.

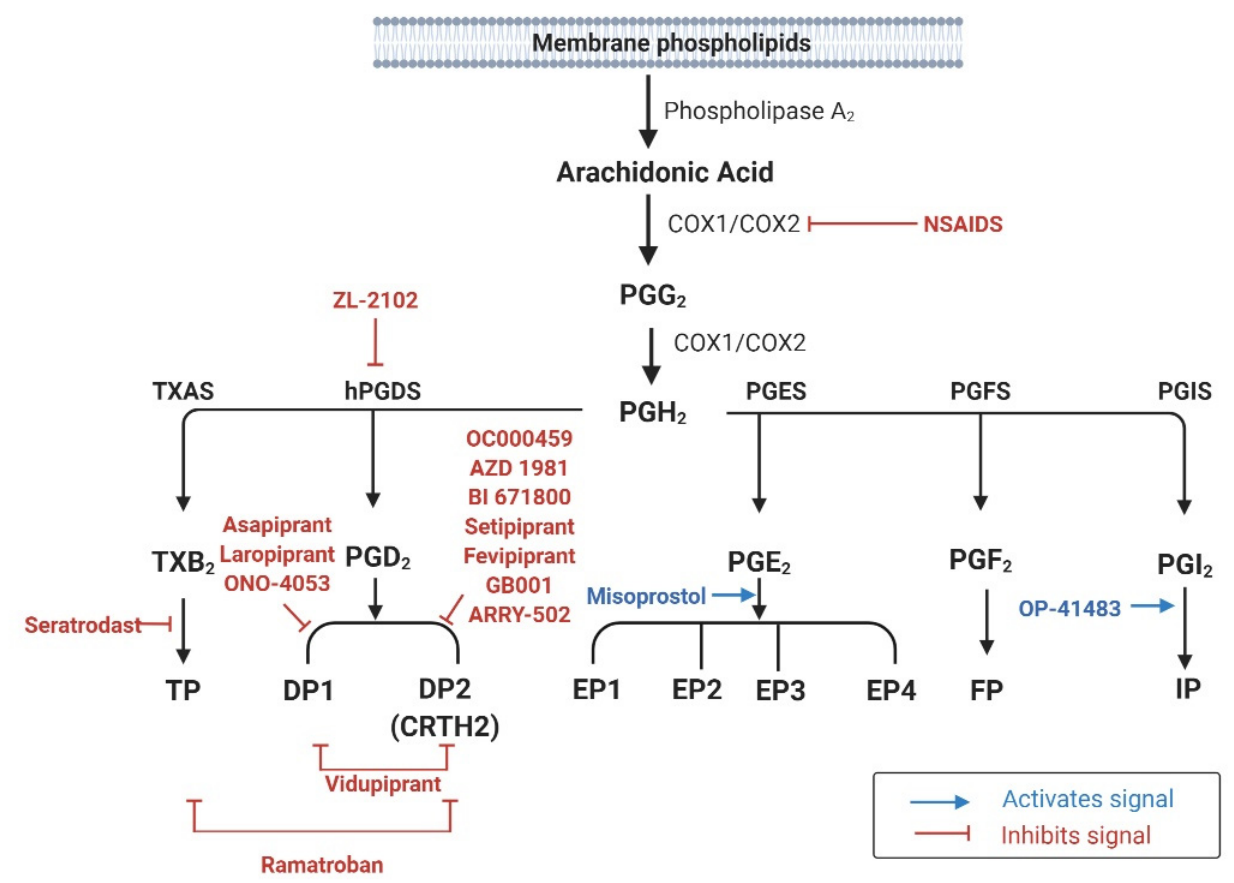

Figure 1. Prostaglandin biosynthesis pathways and pharmacologic agents used in clinical trials for human respiratory allergic diseases. 
In humans, COX-1 and COX-2 comprise the functional COX enzymes, whereas COX-3, which is encoded by COX-1, does not have known function yet. The two homologous COX enzymes have distinct genetic locations and roles in inflammatory reactions. In humans, COX-1 and COX-2 are located on chromosomes 9 and 1, respectively [14]. The expression of COX-1 is constitutive in most tissues, where it participates in the synthesis of homeostatic PGs [15]. However, COX-2 expression is usually transient, and induced by cellular stress or inflammatory reactions, for example after stimulation by lipopolysaccharide (LPS) or the secretion of cytokines, such as interleukin (IL)-1, IL-2, and tumor necrosis factor (TNF)- $\alpha$. COX-2 has been proposed to have a central role in the production of a wide range of PGs during the inflammatory response [15].

\subsection{Generation of Individual PGs and Their Receptors}

$\mathrm{PGH}_{2}$ is believed to be converted immediately to its downstream product rather than accumulating in cells. Except for $\mathrm{PGF}_{2 \alpha}, \mathrm{PGH}_{2}$ metabolites such as $\mathrm{PGD}_{2}, \mathrm{PGE}_{2}, \mathrm{PGI}_{2}$, and $\mathrm{TXA}_{2}$ require specific synthases (Figure 1) [14]. All PGs elicit their biological effects by activating cell surface $G$ protein-coupled receptors (GPCRs) - seven transmembrane spanning receptors [16]. PG receptors are classified into nine subfamilies (DP1, DP2, EP1-4, FP, IP, and TP) according to their affinities for individual PGs (Table 1) [17].

Table 1. Prostaglandins and their specific receptors, downstream signaling, and region of expression.

\begin{tabular}{|c|c|c|c|c|}
\hline Ligands & Production & Receptor & $\begin{array}{l}\text { Downstream } \\
\text { Signaling }\end{array}$ & Receptor Expression \\
\hline \multirow[t]{2}{*}{$\mathrm{PGD}_{2}$} & \multirow{2}{*}{$\begin{array}{c}\text { mast cells, eosinophils, T cells, } \\
\text { dendritic cells, macrophages, } \\
\text { endothelial cells, platelets, } \\
\text { lung parenchyma }\end{array}$} & DP1 & $\uparrow c \mathrm{AMP}$ & $\begin{array}{c}\text { mucus-secreting goblet cells, } \\
\text { nasal serous glands, vascular } \\
\text { endothelial cells, T cells, } \\
\text { dendritic cells, eosinophils }\end{array}$ \\
\hline & & $\begin{array}{c}\text { DP2 } \\
\text { (CRTH2) }\end{array}$ & $\downarrow \mathrm{cAMP}, \uparrow \mathrm{Ca}^{2+}$ & $\begin{array}{l}\text { T cells, basophils, } \\
\text { eosinophils, ILC2 }\end{array}$ \\
\hline \multirow{4}{*}{$\mathrm{PGE}_{2}$} & \multirow{4}{*}{$\begin{array}{l}\text { epithelial cells, fibroblasts, } \\
\text { macrophage, smooth muscle } \\
\text { cells, platelets }\end{array}$} & EP1 & $\uparrow \mathrm{Ca}^{2+}$ & $\begin{array}{l}\text { T cells, dendritic cells, B cells, } \\
\text { smooth muscle cells }\end{array}$ \\
\hline & & $\mathrm{EP} 2$ & $\uparrow c \mathrm{AMP}$ & $\begin{array}{l}\text { T cells, dendritic cells, B cells, } \\
\text { ILC2, mast cells, basophils, } \\
\text { smooth muscle cells }\end{array}$ \\
\hline & & EP3 & $\downarrow$ cAMP & $\begin{array}{l}\text { T cells, B cells, dendritic cells, } \\
\text { smooth muscle cells }\end{array}$ \\
\hline & & EP4 & $\uparrow c A M P$ & $\begin{array}{l}\text { T cells, B cells, dendritic cells, } \\
\text { smooth muscle cells }\end{array}$ \\
\hline $\mathrm{PGF}_{2 \alpha}$ & $\begin{array}{l}\text { lung parenchyma, vascular } \\
\text { smooth muscle cells, } \\
\text { peripheral blood lymphocytes }\end{array}$ & FP & $\uparrow \mathrm{IP} 3 / \mathrm{DAG} / \mathrm{Ca}^{2+}$ & none \\
\hline $\mathrm{PGI}_{2}$ & $\begin{array}{c}\text { endothelial cells, vascular } \\
\text { smooth muscle cells, lung } \\
\text { parenchyma }\end{array}$ & IP & $\uparrow c \mathrm{AMP}$ & $\begin{array}{l}\text { T cells, dendritic cells, B cells, } \\
\text { ILC2, endothelial cells, } \\
\text { platelets }\end{array}$ \\
\hline $\mathrm{TXA}_{2}$ & $\begin{array}{l}\text { platelets, vascular smooth } \\
\text { muscle cells, macrophages }\end{array}$ & $\mathrm{TP}$ & $\begin{array}{c}\uparrow \mathrm{IP} 3 / \mathrm{DAG} / \mathrm{Ca}^{2+}, \\
\uparrow \downarrow c A M P\end{array}$ & megakaryocytes, monocytes \\
\hline
\end{tabular}

PG—prostaglandin; cAMP—cyclic adenosine 3',5'-monophosphate; ILC—innate lymphoid cell; IP-Inositol trisphosphate; DAG—diacylglycerol. An upward arrow $(\uparrow)$ indicates an increased intracellular signaling pathway, and a downward arrow $(\downarrow)$ denotes a decrease in an intracellular signaling pathway.

Two groups of synthases are involved in $\mathrm{PGD}_{2}$ production-hematopoietic- $\mathrm{PGD}_{2}$ synthases (H-PGDS) and lipocalin-PGD ${ }_{2}$ synthases (L-PGDS) [18]—of which only H-PGDS are responsible for $\mathrm{PGD}_{2}$ production by mast cells or other hematopoietic cells, such as eosinophils $[19,20]$. In humans, H-PGDS are abundantly expressed in the lungs, adipose tissue, placenta (at the tissue level), mast cells, $\mathrm{T}$ cells, dendritic cells, and megakaryocytes (at the cellular level) [18]. $\mathrm{PGD}_{2}$ signals through two receptors: DP1 and DP2 (also known as CRTH2). In the airways, DP1 is expressed in the nasal 
mucous-secreting goblet cells, nasal serous glands, vascular endothelium, DCs, T cells, basophils, and eosinophils [21]. DP2 expression has been observed in both hematopoietic cells such as T cells, ILC2s, mast cells, basophils, and eosinophils, as well as in structural cells such as epithelial cells and smooth muscle cells [22]. Stimulation of DP1 increases the intracellular cyclic adenosine $3^{\prime}, 5^{\prime}$-monophosphate (cAMP) level, which is believed to inhibit target cell functions and suppress innate immune functions, for example the generation of inflammatory mediators. Conversely, $\mathrm{PGD}_{2}$ signaling through $\mathrm{DP} 2$ decreases the cAMP level $[14,23]$. In addition to these functions $\mathrm{PGD}_{2}$ can activate the thromboxane receptor (TP), even at low concentrations [24].

Synthesis of $\mathrm{PGE}_{2}$ involves three distinct $\mathrm{PGH}_{2}$-metabolizing enzymes: microsomal PGE synthase (mPGES)-1 and -2, and cytosolic PGE synthase (cPGES) [14]. mPGES-1 is glutathione-dependent, with an inducible expression, and it preferentially catalyzes $\mathrm{PGH}_{2}$ produced by COX-2. In contrast, mPGES-2 utilizes PGE $_{2}$ derived from either COX-1 or COX-2, and it shows constitutive expression in various cell types, including human embryonic kidney cells (HEK293), human colon adenocarcinoma cells (HCA-7) and human lung epithelial cells (BEAS-2B) [25]. cPGES is also expressed constitutively, and it generates $\mathrm{PGE}_{2}$ using $\mathrm{COX}-1$, rather than COX-2. Four distinct receptors, termed EP receptors $1-4$, are activated by $\mathrm{PGE}_{2}$, and are present in various organs associated with allergic reactions, including the lungs [26]. Stimulation of the EP1 receptor causes increase in inositol triphosphate (IP3) and diacylglycerol, followed by increase in intracellular calcium concentrations. Signaling through the EP2 and EP4 receptors is known to increase the intracellular cAMP level, whereas EP3 activation results in decreased cAMP synthesis in cells [14].

The formation of $\mathrm{PGF}_{2 \alpha}$ is catalyzed by PGF synthase (PGFS) via two pathways, utilizing NADPH and $\mathrm{PGD}_{2}$, respectively [27]. PGFS has been identified in lung and peripheral blood lymphocytes, suggesting their role in inducing airway allergic reactions [27]. A single receptor, termed FP, mediates $\mathrm{PGF}_{2 \alpha}$ signaling. FP has high affinity for $\mathrm{PGF}_{2}$, and its stimulation results in an increase in intracellular calcium concentrations [16].

$\mathrm{PGI}_{2}$ is generated from $\mathrm{PGH}_{2}$ by PGI synthase, which is highly expressed in the lungs, smooth muscle, heart, kidneys, and ovaries [28]. $\mathrm{PGI}_{2}$ activates adenylate cyclase and increases intracellular cAMP levels by stimulating its receptor, known as IP [16], which is strongly expressed in the thymus, lungs, heart, spleen, and neurons [28].

$\mathrm{TXA}_{2}$ accounts for the majority of AA metabolites, but it is unstable in nature, with a short half-life of $30 \mathrm{~s}$ [26]. TXA $\mathrm{A}_{2}$ is hydrolyzed to thromboxane $\mathrm{B}_{2}\left(\mathrm{TXB}_{2}\right)$ in the absence of an enzyme. The synthase that catalyzes the formation of $\mathrm{TXA}_{2}$ from $\mathrm{PHG}_{2}$ is named thromboxane synthase, which shows strong expression in the lungs, kidneys, liver, monocytes, and megakaryocytes [29]. TX $\mathrm{A}_{2}$ is predominantly produced by cells such as platelets, neutrophils, monocytes, macrophages, and lung parenchyma cells [30]. TXA 2 signals through its receptor TP, which has two isoforms, TP $\alpha$ and TP $\beta$. Although both of these isoforms lead to phospholipase $\mathrm{C}$ activation, calcium release, and protein kinase $\mathrm{C}$ activation, they have opposing functions when coupled to a Gq protein: TP $\alpha$ activates adenylate cyclase, followed by increased cAMP levels and the induction of cAMP-dependent intracellular signaling pathways, while TP $\beta$ inhibits them [31].

\section{The Role of Prostaglandins in Various Cell Types Involved in Allergic Reactions}

Allergic respiratory reactions occur because of interactions between various cells and cytokines [32]. When an allergen reaches the respiratory mucosa, epithelial cells and ILC2 secrete cytokines, while DCs present allergens, resulting in Th2 differentiation of naïve $\mathrm{T}$ cells and IgE production from $\mathrm{B}$ cells $[33,34]$. Eosinophilic inflammation caused by intercellular reactions leads to epithelial mucus hypersecretion, bronchoconstriction, and airway remodeling. PGs affect all stages of this reaction [35] (Figure 2). 


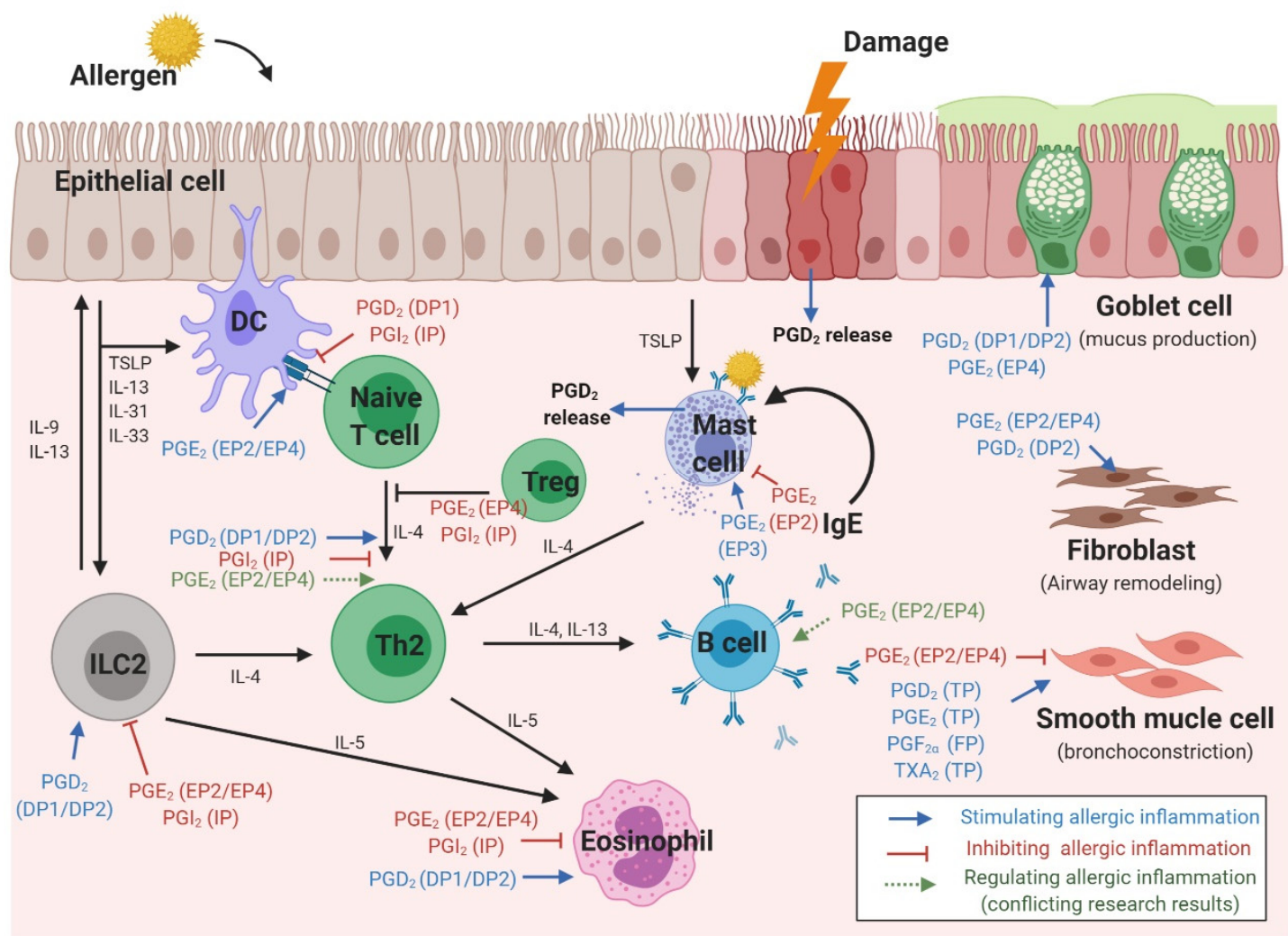

Figure 2. Stimulatory and inhibitory effects of prostaglandins, and their receptors, in different cell types involved in the pathophysiology of respiratory allergies.

\subsection{Epithelial Cells}

In human nasal polyps, stronger expression of $\mathrm{H}-\mathrm{PGDS}$ and $\mathrm{PGD}_{2}$ was observed than in normal nasal mucosa. Moreover, $\mathrm{PGD}_{2}$ in airway epithelial cells induced increased MUC5B expression and mucin hypersecretion by the DP1 receptor [36,37]. A recent study using primary bronchial epithelial cell reported that $\mathrm{PGD}_{2}$ promoted epithelial cell migration as well as goblet cell hyperplasia, which were attenuated by DP2-selective antagonist [38].

Human bronchial epithelial cells treated with IL-13 showed increased airway mucin production, with increased expression of the mucin gene MUC5AC after $\mathrm{PGE}_{2}$ stimulation via the EP4 receptor [39]. Moreover, epithelial cells derived from the nasal polyps of patients with aspirin sensitivity showed dysregulated AA metabolism, which abnormally reduced the spontaneous production of $\mathrm{PGE}_{2}$, suggesting a mechanism of chronic inflammation in these patients [40]. $\mathrm{PGE}_{2}$ derived from epithelial cells also affected cells such as DCs and smooth muscle cells. Activation of the EP4 receptor by $\mathrm{PGE}_{2}$ released from airway epithelial cells limits DC activation and reduces the pro-inflammatory properties of DCs [41]. In addition, epithelia-derived $\mathrm{PGE}_{2}$ generated in response to bradykinin stimulation reduces airway smooth muscle contraction [42].

\subsection{Dendritic Cells}

The maturation and migration of DCs is affected by PGs (Figure 3) [2]. In the presence of $\mathrm{PGE}_{2}$, CCL7 ligands triggered DC migration through the activation of signaling pathways, including cAMP-dependent PKA and rho kinase [43]. Interestingly, the presence of $\mathrm{PGE}_{2}$ was found to be effective only at initiation, and not termination, of DC maturation. In addition, modulation of DC migration by $\mathrm{PGE}_{2}$ reportedly requires a signal in the form of stimulation of either EP2, EP4, or both $[44,45]$. In contrast, $\mathrm{PGD}_{2}$ and $\mathrm{PGI}_{2}$ reduce $\mathrm{DC}$ maturation and migration. The inhibitory effect of $\mathrm{PGD}_{2}$ administration was observed in Balb/c mice exposed to fluorescein isothiocyanate (FITC)-OVA 
inhalation as a decreased migration of FITC + DC to draining lymph nodes. This effect was also mediated by a DP1 agonist, but not by a DP2 agonist, suggesting that DP1 is responsible for modulating DC migration [46]. Another study showed that DP1 activation in DCs induced FOXP3 (+), CD4 (+), and regulatory $\mathrm{T}$ (Treg) cells, but DP1 depletion in DCs enhanced Th2 response in the airways, supporting this hypothesis [47]. In a murine model of asthma, inhalation of a stable $\mathrm{PGI}_{2}$ analog, iloprost, reduced the maturation and migration of lung DCs, thereby reducing the allergen-specific Th2 response in mediastinal lymph nodes [48]. In addition, iloprost treatment of DCs decreased differentiation of naïve T cells into effector Th2 cells [49].

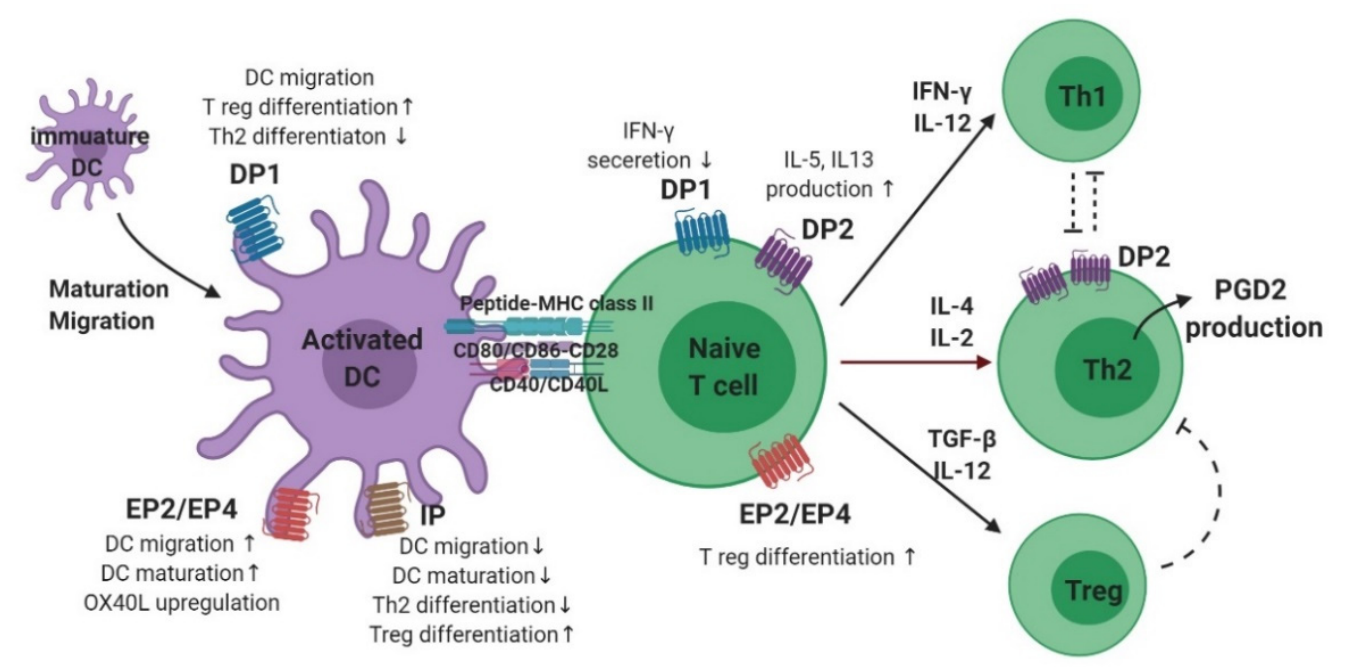

Figure 3. The role of prostaglandins and their receptors in dendritic cell-T cell interaction and Th2 differentiation.

$\mathrm{PGE}_{2}$ also has an important role in DC-T cell interactions as well as $\mathrm{T}$ cell differentiation (Figure 3). For Th1/Th2 balance, the ratio between $\mathrm{PGE}_{2}$ and IL-12 from DCs is important, suggesting that $\mathrm{PGE}_{2}$ induces Th2-skewing responses by inhibiting IL-12 production [50-52]. Reduction of IL-12 by $\mathrm{PGE}_{2}$ also inhibits interferon (IFN)- $\gamma$ release from $\mathrm{T}$ cells and natural killer cells [51,53]. A recent study revealed a new mechanism for activation of Th2 immune response mediated by DCs, wherein allergen-induced $\mathrm{PGE}_{2}$ secretion by DCs resulted in autocrine OX40 ligand upregulation [54]. In a study on murine bone marrow-derived DCs (BMDCs), PGE 2 inhibited TNF- $\alpha$ and IL-6 secretion by inducing IL-10 [55-57]. However, in the presence of TNF- $\alpha, \mathrm{PGE}_{2}$ stimulation of human BMDCs increased IL-12 production, inducing a Th1 response [58,59]. In addition, BMDCs stimulated by $\mathrm{PGE}_{2}$ promoted IL-23 production, and induced Th17 differentiation [60]. In a recently published study of an OVA-induced asthma model, treatment of DCs with a $\mathrm{PGI}_{2}$ analogue, iloprost, induced differentiation of naïve $\mathrm{T}$ cells to Treg cells, leading to immune tolerance [61].

\subsection{T Cells}

$\mathrm{PGD}_{2}$ production was found to occur preferentially in antigen-stimulated human Th2 cells, but not in Th1 cells (Figure 3) [26]. $\mathrm{PGD}_{2}$ inhibits IFN- $\gamma$ secretion by activating DP1, and stimulates Th2 cytokine expression through DP2 (CRTH2) activation [62]. A more recent study showed that the IL-5 positive effector $\mathrm{T}$ cell population expressing the CRTH2 receptor, was the pro-inflammatory Th2 cell population and induced allergic inflammation [63]. Moreover, mast cell-derived $\mathrm{PGD}_{2}$ activated type-2 CD8 (+) T cells via the CRTH2 receptor, inducing migration and cytokine (IL-5 and IL-13) production in severe eosinophilic asthma [64]. Studies supporting these findings have shown that a larger population of CRTH2 (+) T cells was identified from the peripheral blood of patients with severe asthma, and allergen-specific Th2 cells could be identified by stable co-expression of CRTH2 [65-67]. 
$\mathrm{PGE}_{2}$ has been proposed to induce Th2 responses by attenuating the production of IL- 2 and IFN- $\gamma$ by Th1 cells without enhancing the release of IL-4 by Th2 cells $[26,68]$. In an in vitro study, $\mathrm{PGE}_{2}$ stimulation of CD4 (+) T cells downregulated not only Th1 cytokines such as IFN- $\gamma$ and TNF- $\alpha$, but also IL-4. Nevertheless, differentiation skewed toward Th2, because of a much stronger inhibition of Th1 cytokine production [69]. However, studies regarding individual $\mathrm{PGE}_{2}$ receptors have shown conflicting results. Increased cAMP signaling via $\mathrm{PGE}_{2}-\mathrm{EP} 2 / \mathrm{EP} 4$ in naïve $\mathrm{T}$ cells promoted the upregulation of IL-12R $\beta 2$ and IFN- $\gamma$ R1, thereby inducing Th1 differentiation [70]. The endogenous $\mathrm{PGE}_{2}-\mathrm{EP} 2$ axis was shown to have a role in controlling allergen sensitization and reducing theTh2 immune response in a murine model of asthma [71]. Furthermore, recent studies have shown that endogenous $\mathrm{PGE}_{2}$ coupled with the EP2-EP4 receptor induces the activation of pathogenic Th17 cells in both murine and human T cells [72,73]. Another study showed that $\mathrm{PGE}_{2}$ stimulation of $\mathrm{T}$ cells from the peripheral blood of patients with allergic rhinitis caused them to differentiate into Treg cells via EP4 receptor activation [74]. Although conflicting results have been reported on whether $\mathrm{PGE}_{2}$ induces differentiation of naïve T cells to Th1 or Th2, there is a consensus on the effect of $\mathrm{PGE}_{2}$ in Treg cell-induced inhibition of effector T cells [75].

\subsection{B Cells}

Most studies on the role of PGs in B cells have investigated the effect of $\mathrm{PGE}_{2}$ on the development of $\mathrm{B}$ cells and their production of IgE. However, studies on the role of $\mathrm{PGE}_{2}$ on IgE production have shown conflicting results. In the most recent study, B cells from EP2-deficient mice showed impaired IgE production and airway inflammation after an OVA challenge, suggesting the role of $\mathrm{PGE}_{2}-\mathrm{EP} 2$ signaling in promoting IgE production in allergic inflammation [76]. In support of this finding, $\mathrm{PGE}_{2}$ was shown to promote immunoglobulin class switching to IgE in B cells in the presence of IL- 4 and LPS [77]. In contrast, $\mathrm{PGE}_{2}$ was shown to reduce MHC-II expression in B cells and suppress IgE production, which was mediated by either EP2 or EP4 [78]. Another study on B cell responses in an OVA-induced asthma murine model also showed that EP2 deficiency resulted in elevation of serum IgE level [71]. Taken together, although the exact effect of $\mathrm{PGE}_{2}$ is unclear, these studies emphasize the role of $\mathrm{PGE}_{2}$ in modulating IgE production.

\subsection{Type 2 Innate Lymphoid Cells}

The relationship between ILC2 cell function and PGs in allergic disease was first reported in a study showing that $\mathrm{PGD}_{2}$ released from mast cells induced IL-13 production by ILC2 cells, via DP1 or DP2 receptors (Figure 4) [79]. ILC2 cells obtained from the peripheral blood of patients with allergic rhinitis induced IL-5 production after stimulation by $\mathrm{PGD}_{2}$ [80]. Furthermore, activation of DP2 receptor on human ILC2 cells induced their migration, production of type 2 cytokines, and increased expression of receptors for IL-33 and IL-25 [81]. ILC2 accumulation, induced by IL-33, was not observed in a DP2-deficient murine model [82]. In the sputum of patients with asthma, a DP2-positive ILC2 population, in addition to IL-5- or IL-13-positive ILC2s, was observed to be significantly higher after allergen challenge than in the controls [83]. In addition, the number of ILC2s after allergen challenge was elevated in the bronchoalveolar lavage (BAL) fluid and reduced in the blood. $\mathrm{PGD}_{2}$ levels in the BAL fluid showed a significant correlation with a decrease in ILC2 in the blood, indicating that $\mathrm{PGD}_{2}$ is essential for ILC2 migration [84]. In patients with AERD, recruitment of ILC2 to the nasal mucosa was observed upon treatment with a COX-1 inhibitor, with a corresponding decrease in ILC2 numbers in the blood, supporting the correlation with enhanced $\mathrm{PGD}_{2}$ production [85]. Further supporting these findings, ILC2s isolated from human blood that were treated with the $\mathrm{PGD}_{2}$ antagonist, fevipiprant, showed reduced aggregation and diminished cytokine production [86]. Moreover, human ILC2 cells treated with the H-PGDS enzyme inhibitor, KMN698, showed a diminished release of IL-5 and IL-13 [87]. 


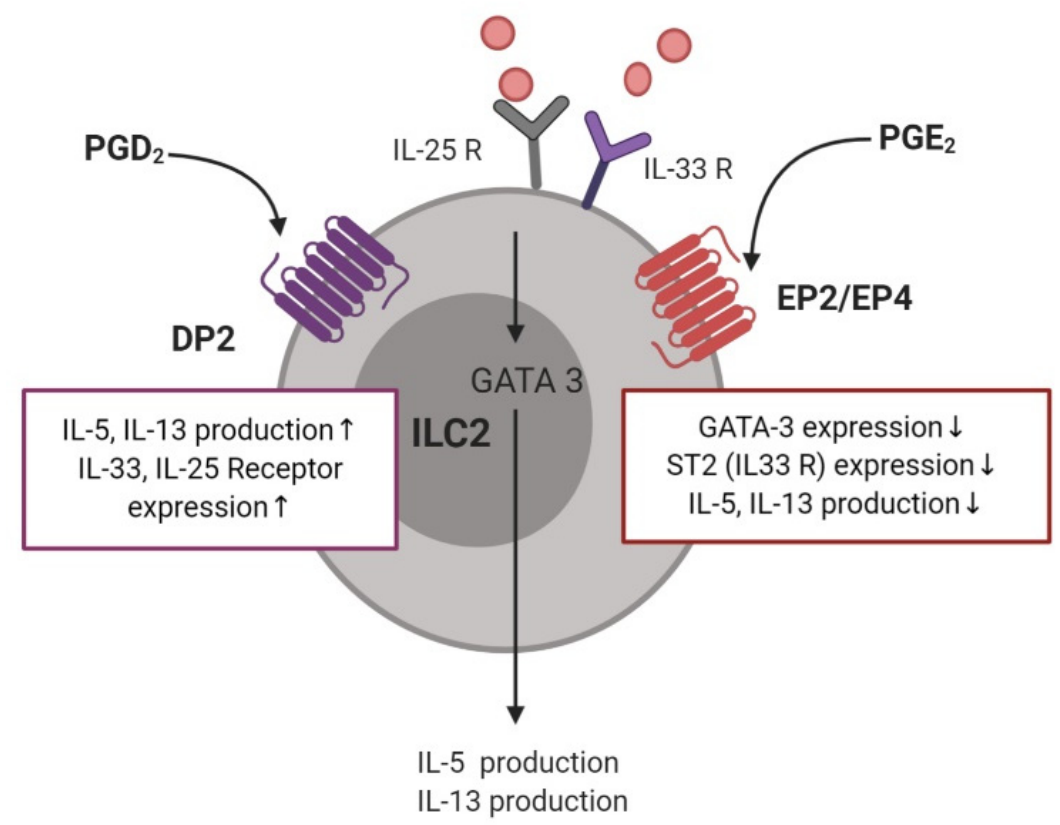

Figure 4. The role of prostaglandins and their receptors in type 2 innate lymphoid cells.

Among four receptors for $\mathrm{PGE}_{2}$, only the EP2 and EP4 receptors showed strong expression in single-cell transcriptome sequencing of human tonsillar ILC2 cells [88]. In the same study, $\mathrm{PGE}_{2}$ attenuated ILC2 function by inhibiting GATA-3 expression, and decreasing the release of Th2 cytokines, including IL-5 and IL-13. Another study revealed that PGE $_{2}-E P 4-c A M P$ signaling inhibited IL-33-induced Th2 cytokine production in pulmonary ILC2 cells by suppressing GATA3 and ST2 expression [89]. Similarly, PGI $_{2}$ inhibited the expression of IL-5 and IL-13 in IL-33-stimulated ILC2 cells from the bone marrow in a mouse model challenged intranasally with Alternaria alternata [90].

\subsection{Eosinophils}

PG receptors expressed on human eosinophils include DP1 and DP2 for PGD 2 EP2 and EP4 for $\mathrm{PGE}_{2}$, and IP for $\mathrm{PGI}_{2}$ (Figure 5) [91].

Both DP1 and DP2 are present on the surface of eosinophils [92]. In addition to $\mathrm{PGD}_{2}$-induced stimulation of these receptors, the major metabolite of $\mathrm{PGD}_{2}, 15$-deoxy- $\Delta 12,14-\mathrm{PGJ}_{2}$, activates the peroxisome proliferator-activated receptor- $\gamma$ on eosinophils [93]. $\mathrm{PGD}_{2}$ is known to modulate eosinophil migration via the DP2 receptor [94,95]. $\mathrm{PGD}_{2}$-DP2 signaling also enhances $\mathrm{Ca}^{2+}$ morphologic changes and degranulation of eosinophils in allergic inflammatory responses [94]. A recent study revealed that blocking the $\mathrm{PGE}_{2}$-DP2 pathway inhibits migration of eosinophils toward mast cells-the initial stage in an allergic reaction [96]. In addition, by mediating its effect through DP2, $\mathrm{PGD}_{2}$ also enhances the function of other chemoattractants, such as eotaxin, complement factor C5a, or 5-oxo-6,8,11,14-eicosatetraenoic acid (5-oxo-ETE) on eosinophils [97,98]. In contrast, eotaxin and 5-oxo-ETE diminished eosinophil migration toward $\mathrm{PGD}_{2}$, and their effect was decreased in the presence of blood or plasma, while no effect was identified for $\mathrm{PGD}_{2}$, suggesting that it acts as the initial chemoattractant, while eotaxin is the endpoint chemoattractant [98]. The DP1 receptor on eosinophils inhibits eosinophil apoptosis and cooperates with DP2 receptors to induce $\mathrm{LTC}_{4}$ synthesis, eosinophil mobilization, and pro-inflammatory signaling $[92,94,99,100]$. In eosinophils obtained from the peripheral blood of patients with AERD, high expression of H-PGDS was identified, and inhibitory action of the H-PGDS enzyme suppressed the release of $\mathrm{PGD}_{2}$ [101]. This suggests that eosinophil activation could occur via autocrine signaling in patients with AERD and allergic inflammation [20].

In eosinophils, $\mathrm{PGE}_{2}$ decreases the production of the eosinophil cationic protein and the aggregation of eosinophils [102,103]. EP2 receptor activation in eosinophils attenuates eosinophil 
trafficking and $\mathrm{PGE}_{2}-\mathrm{EP} 4$ signaling, and decreases migration and degranulation of eosinophils [104,105]. $\mathrm{PGE}_{2}$ also inhibits the spontaneous apoptosis of eosinophils in human peripheral blood and suppresses eosinophil-endothelial cell interactions, including adhesion and transmigration, by altering $\beta_{2}$ integrin and L-selectin function [106,107]. Eosinophils obtained from human peripheral blood showed reduced production of $\mathrm{LTB}_{4}$ and cysteinyl LTs (cysLTs) when treated with a low dose of $\mathrm{PGE}_{2}$ after lysine aspirin stimulation, and this effect was mediated by EP2 receptor activation [108].

$\mathrm{PGI}_{2}$ has similar properties to $\mathrm{PGE}_{2}$, as both act as immune suppressors in eosinophils through the IP receptor, and both modulate intracellular cAMP [91]. In guinea pigs, both $\mathrm{PGI}_{2}$ and a $\mathrm{PGI}_{2}$ analogue, iloprost, inhibit bone marrow eosinophil trafficking [109]. In addition, endothelial-derived $\mathrm{PGI}_{2}$ negatively modulates eosinophil-endothelial interactions by inhibiting eosinophil adhesion and transendothelial migration [110].

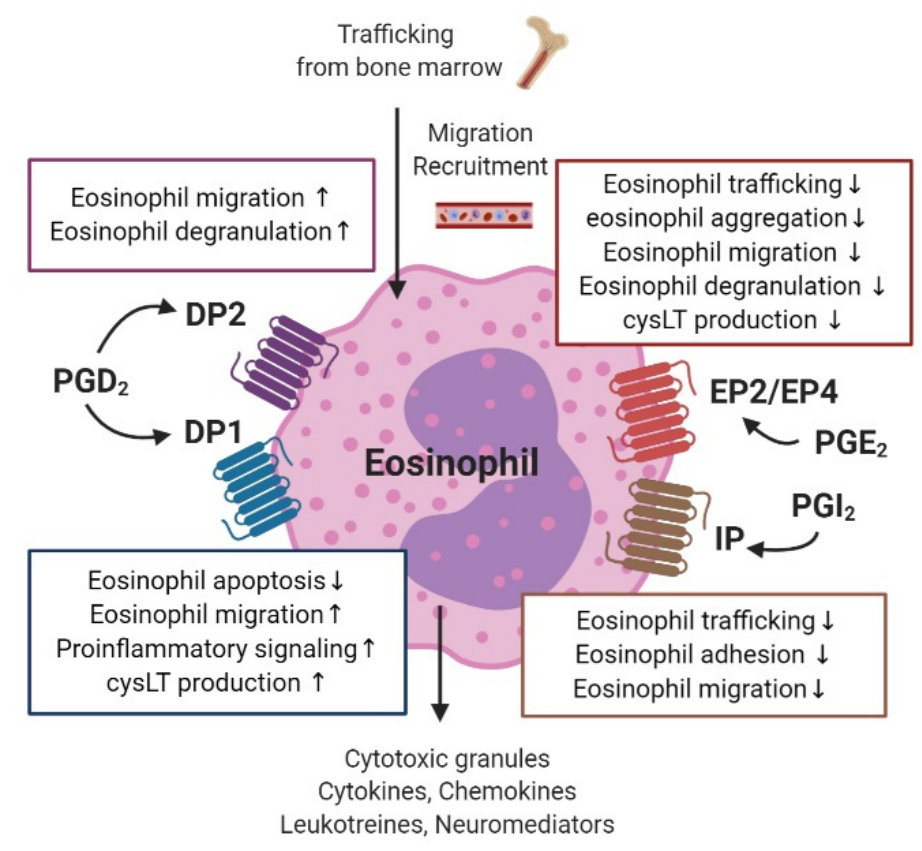

Figure 5. The role of prostaglandins and their receptors in eosinophil function, including bone marrow trafficking, migration, and degranulation.

\subsection{Mast Cells}

Mast cells are an important source of endogenous eicosanoids, and $\mathrm{PGD}_{2}$ is the predominantly released mediator, with cysLTs. Production of $\mathrm{PGD}_{2}$ from mast cells isolated from human lungs depends on COX-1 and H-PGDS, but not L-PGDS [111]. In the nasal mucosa of patients with allergic rhinitis, the number of mast cells with H-PGDS expression was high, while that with L-PGDS expression was low [21]. In humans, there was a linear correlation between $\mathrm{PGD}_{2}$ generation and histamine secretion after IgE-dependent activation of human mast cells [19]. A recent study, using nasal polyp tissue from patients with chronic rhinosinusitis and AERD, showed that TSLP induces the production of $\mathrm{PGD}_{2}$ by mast cells [112]. Another recent study showed intracellular expression of DP2 receptors in mast cells isolated from nasal polyps [113]. However, the majority of mast cells (either cell-line-derived human mast cells or cells harvested from the nasal cavity) did not express the $\mathrm{PGD}_{2}$ receptors, and did not respond to a DP2 agonist or antagonist [114].

Human mast cells also express EP2, EP3, and EP4 receptors for $\mathrm{PGE}_{2}$ signaling, and $\mathrm{PGE}_{2}$ stimulation coupled with EP2 activation inhibited mast cell degranulation, whereas EP3 receptor activation enhanced mast cell mediator release [115-117]. 


\subsection{Smooth Muscle Cells}

The role of PGs in modulating contraction of airway smooth muscles is widely accepted [39]. Four distinct receptors $\left(\mathrm{PGE}_{2}, \mathrm{EP} 2, \mathrm{EP} 3\right.$, and EP4) have been detected on human airway smooth muscle cells [118]. Inhalation of $\mathrm{PGE}_{2}$ diminished bronchoconstriction in a methacholine airway test after an allergen challenge, and decreased bronchoconstriction induced by exercise or aspirin [119]. In humans, the EP4 receptor appears to mediate this effect, as a selective EP4 agonist could reverse the histamine-induced contraction of airway smooth muscle cells [120]. In other species, including mice, guinea pigs, and monkeys, $\mathrm{PGE}_{2}$-mediated regulation of smooth muscle contraction was regulated by EP2 [121]. Conversely, the activation of $\mathrm{PGE}_{2}$ is known to induce bronchial contraction, emphasizing the importance of receptor selectivity. In a recent study, bronchoconstriction caused by $\mathrm{PGE}_{2}$ and other PGs involved TP receptor activation pathways, and the powerful bronchoprotective effect of $\mathrm{PGE}_{2}$ was generated through mast cell-mediated bronchoconstriction via activation of the EP2 receptor, while EP4 stimulation had less efficacy than a long-acting $\beta$-receptor agonist [121]. In addition to muscle tone regulation in airway cultured smooth muscle cells, $\mathrm{PGE}_{2}$ limits the release of the granulocyte macrophage-colony stimulating factor, an important mediator of allergic inflammation and eosinophil survival [122]. Moreover, $\mathrm{PGE}_{2}$-induced stimulation of the EP2 or EP4 receptors inhibits migration of smooth muscle cells of the airways through the cAMP/PKA pathway, suggesting a potential pharmacological role of $\mathrm{PGE}_{2}$ in preventing airway remodeling in asthma [123].

In contrast to $\mathrm{PGE}_{2}, \mathrm{PGD}_{2}$ acts as a bronchoconstrictor and has a potent effect on muscle contraction, mediated via the TP receptor [24]. In humans, the increase in nasal resistance induced by $\mathrm{PGD}_{2}$ nasal instillation was greater than that of histamine (10-fold) or bradykinin (100-fold) [24]. A recent in vitro study showed that inhibition of the $\mathrm{PGD}_{2}$-DP2 pathway reduced the migration of airway smooth muscle cells, suggesting a role for DP2 antagonists in airway remodeling [124].

$\mathrm{PGF}_{2 \alpha}$ inhalation in healthy and asthmatic subjects caused bronchoconstriction in a dose-dependent manner; however, the sensitivity was approximately 150 times greater in asthmatic patients than in healthy controls [125]. In healthy controls, the responsive dose varied widely across individuals, but females generally had a smaller contractile response to $\mathrm{PGF}_{2 \alpha}$ than males [125].

$\mathrm{TXA}_{2}$ is also reported to be a potent bronchoconstrictor. In asthmatic patients, bronchoconstriction induced by antigen inhalation was shown to involve high concentrations of $\mathrm{TXB}_{2}$, which is a stable metabolite of $\mathrm{TXA}_{2}$, suggesting the possible role of $\mathrm{TXA}_{2}$ in airway remodeling or hyper-responsiveness [126]. This effect was mediated through c-Jun N-terminal kinase-mitogen-activated protein kinase signaling, and increased the extracellular calcium influx after stimulation of the TP receptor [127].

\subsection{Fibroblasts (in Nasal Polyps)}

The role of PGs in fibroblasts has also been studied, as formation of eosinophilic nasal polyps is a typical phenotype of patients with dysregulated AA metabolism.

Nasal polyp-derived fibroblasts showed increased production of vascular endothelial growth factor after $\mathrm{PGE}_{2}$ stimulation via EP4 receptor activation, indicating that $\mathrm{PGE}_{2}$ has a role in increased micro-vascular permeability during tissue remodeling in nasal polyps [128]. In a study using cultured fibroblasts from healthy nasal mucosa and nasal polyps from patients with aspirin-tolerant and -sensitive asthma, $\mathrm{PGE}_{2}$ concentration was lower in patients with both aspirin-tolerant and -sensitive nasal polyps after IL-1 $\beta$ stimulation, than in the controls [129]. In addition, increased expression of the EP2 receptor in fibroblasts after IL-1 $\beta$ stimulation was identified only in normal mucosa, but not in nasal polyps from either aspirin-tolerant or -sensitive patients [129]. Another study suggested that decreased expression of the EP2 receptor in fibroblasts from nasal polyps of patients with AERD resulted in resistance to the anti-proliferative effects of $\mathrm{PGE}_{2}$ [130].

$\mathrm{PGD}_{2}$ stimulation also induced the release of vascular endothelial growth factor, but this release occurred via the DP1 receptor, not the DP2 receptor [131]. 


\section{Clinical Studies of Prostaglandins in Allergic Airway Diseases}

The expression and role of PGs in allergic airway diseases have been studied for a long time. Recently, clinical phase II and III studies were conducted to evaluate the therapeutic effects of PGs, especially for asthma and allergic rhinitis (Table 2). This section briefly introduces the role of PGs in each disease (asthma, allergic rhinitis, AERD, and nasal polyps) in clinical settings, and provides an overview of the clinical studies that have used pharmacologic agents targeting PGs.

Table 2. Summary of clinical studies on pharmacologic agents targeting PGs in asthma and allergic rhinitis.

\begin{tabular}{|c|c|c|c|}
\hline Drug and Dose & $\begin{array}{c}\text { Indication } \\
\text { (Sample Size) }\end{array}$ & Key Results & Ref. \\
\hline \multicolumn{4}{|l|}{ DP2 antagonist } \\
\hline $\begin{array}{l}\text { Fevipiprant (QAW039), oral } \\
\text { administration, } 500 \text { mg daily for } 28 \text { days }\end{array}$ & $\begin{array}{l}\text { Mild to moderate uncontrolled } \\
\text { allergic asthma } \\
\qquad(n=170)\end{array}$ & $\begin{array}{l}\text { Improvement of lung function in } \\
\text { patients with } \mathrm{FEV}_{1}<70 \%\end{array}$ & [132] \\
\hline $\begin{array}{c}\text { Fevipiprant (QAW039), oral } \\
\text { administration, } 1-450 \mathrm{mg} \text { daily or } \\
2-150 \mathrm{mg} \text { twice daily, with inhaled } \\
\text { budesonide } 200 \mu \mathrm{g} \text { twice a day, for } \\
12 \text { weeks }\end{array}$ & $\begin{array}{l}\text { Allergic asthma uncontrolled by } \\
\text { a low-dose inhaled } \\
\text { corticosteroid } \\
(n=2598)\end{array}$ & $\begin{array}{l}\text { Total daily dose of } 150 \mathrm{mg}(150 \mathrm{mg} \text { once } \\
\text { or } 75 \mathrm{mg} \text { twice per a day) showed } \\
\text { an improvement in forced } \\
\text { expiratory volume }\end{array}$ & [133] \\
\hline $\begin{array}{c}\text { Fevipiprant (QAW039), oral } \\
\text { administration, } 225 \mathrm{mg} \text { twice daily for } \\
12 \text { weeks }\end{array}$ & $\begin{array}{l}\text { Moderate to severe asthma with } \\
\text { serum eosinophil } \geq 2 \% \\
\qquad(n=61)\end{array}$ & Decreased sputum eosinophil count & [134] \\
\hline $\begin{array}{l}\text { ARRY-502, oral administration, } 200 \mathrm{mg} \\
\text { twice daily for four weeks }\end{array}$ & $\begin{array}{l}\text { Mild allergic asthma } \\
\qquad(n=184)\end{array}$ & $\begin{array}{l}\text { Reduction of FeNO level and decreased } \\
\text { serum markers of Th2 inflammation }\end{array}$ & [135] \\
\hline $\begin{array}{l}\text { AZD1981, oral administration, } 100 \mathrm{mg} \\
\text { twice daily }\end{array}$ & $\begin{array}{l}\text { Stable asthma withdrawn from } \\
\text { inhaled corticosteroid } \\
\qquad(n=209)\end{array}$ & $\begin{array}{l}\text { No efficacy on morning peak } \\
\text { expiratory flow }\end{array}$ & [136] \\
\hline $\begin{array}{l}\text { AZD1981, oral administration, } \\
50-1000 \mathrm{mg} \text { twice daily, for four weeks, } \\
\text { with an inhaled corticosteroid }\end{array}$ & $\begin{array}{l}\text { Asthma uncontrolled by inhaled } \\
\text { corticosteroid } \\
\qquad(n=510)\end{array}$ & $\begin{array}{c}400 \text { mg group showed improved } \mathrm{FEV}_{1}, \\
\text { significant improvement in } \\
\text { questionnaire score and } \mathrm{FEV}_{1} \text { in } \\
\text { atopic subgroup }\end{array}$ & [136] \\
\hline $\begin{array}{l}\text { OC000549, oral administration, } 25 \mathrm{mg} \\
\text { daily/200 mg daily/100 mg twice daily, } \\
\text { for } 12 \text { weeks, with use of short-acting } \\
\beta 2 \text { agonist }\end{array}$ & $\begin{array}{l}\text { Mild to moderate asthma } \\
\qquad(n=460)\end{array}$ & $\begin{array}{l}\text { Improved } \mathrm{FEV}_{1} \text { (prominent in } \\
\text { eosinophilic subjects), lower incidence } \\
\text { of symptom exacerbation and } \\
\text { respiratory infection }\end{array}$ & [137] \\
\hline $\begin{array}{l}\text { OC000549, oral administration, } 200 \mathrm{mg} \\
\text { twice daily for eight days }\end{array}$ & $\begin{array}{l}\text { Seasonal allergic rhinitis } \\
\qquad(n=35)\end{array}$ & $\begin{array}{l}\text { Reduced grass-pollen induced nasal } \\
\text { and ocular symptoms }\end{array}$ & [138] \\
\hline $\begin{array}{l}\text { GB001, oral administration, } 30 \mathrm{mg} \text { daily } \\
\text { for } 28 \text { days, with use of low dose } \\
\text { inhaled fluticasone propionate }\end{array}$ & $\begin{array}{l}\text { Mild to moderate atopic asthma } \\
\qquad(n=36)\end{array}$ & $\begin{array}{l}\text { Improved } \mathrm{FEV}_{1} \text { (prominent in patients } \\
\text { with high FeNO or high blood } \\
\text { eosinophil) }\end{array}$ & [139] \\
\hline $\begin{array}{l}\text { BI671800, oral administration, } \\
50 / 200 / 400 \mathrm{mg} \text { twice daily for six weeks }\end{array}$ & $\begin{array}{l}\text { Mild to moderate asthma } \\
\qquad(n=389)\end{array}$ & $\begin{array}{l}\text { Greater improvement in } \mathrm{FEV}_{1} \\
\text { compared to moderate doses of } \\
\text { fluticasone }\end{array}$ & [140] \\
\hline $\begin{array}{c}\text { BI671800, oral administration, } 400 \mathrm{mg} \\
\text { twice daily with inhaled fluticasone } \\
(88 \mu \mathrm{g})\end{array}$ & $\begin{array}{l}\text { Mild to moderate asthma with } \\
\text { inhaled corticosteroid }(n=243)\end{array}$ & $\begin{array}{l}\text { Improvement in } \mathrm{FEV}_{1} \text { compared to } \\
\text { placebo; however, not significantly } \\
\text { improved over montelukast }\end{array}$ & [140] \\
\hline $\begin{array}{l}\text { Setipiprant (ACT-129968), oral } \\
\text { administration, } 1000 \mathrm{mg} \text { twice daily for } \\
\text { five days, washout period of } \\
\text { three weeks }\end{array}$ & $\begin{array}{l}\text { Stable allergic asthma } \\
\qquad(n=15)\end{array}$ & $\begin{array}{l}\text { Reduction in both allergen-induced late } \\
\text { asthmatic responses and airway } \\
\text { hyper-responsiveness }\end{array}$ & [141] \\
\hline $\begin{array}{l}\text { Setipiprant (ACT-129968), oral } \\
\text { administration, 100/500/1000 mg twice } \\
\text { daily or } 1000 \mathrm{mg} \text { daily for two weeks }\end{array}$ & $\begin{array}{l}\text { Seasonal allergic rhinitis } \\
\qquad(n=557)\end{array}$ & $\begin{array}{l}\text { Dose-related improvements in both } \\
\text { nasal and ocular symptom scores }\end{array}$ & [142] \\
\hline $\begin{array}{c}\text { Setipiprant (ACT-129968), oral } \\
\text { administration, } 1000 \text { mg twice daily for } \\
\text { two weeks }\end{array}$ & $\begin{array}{l}\text { Seasonal allergic rhinitis } \\
\qquad(n=604)\end{array}$ & $\begin{array}{l}\text { No significant effect on either nasal or } \\
\text { ocular symptom scores }\end{array}$ & [142] \\
\hline
\end{tabular}


Table 2. Cont.

\begin{tabular}{|c|c|c|c|}
\hline Drug and Dose & $\begin{array}{c}\text { Indication } \\
\text { (Sample Size) }\end{array}$ & Key Results & Ref. \\
\hline \multicolumn{4}{|l|}{ Dual antagonist for DP2 and TP } \\
\hline $\begin{array}{c}\text { Ramatroban (BYAu3405), oral } \\
\text { administration, } 150 \mathrm{mg} \text { twice daily for } \\
\text { four weeks }\end{array}$ & $\begin{array}{l}\text { Perianal allergic rhinitis } \\
\qquad(n=10)\end{array}$ & $\begin{array}{l}\text { Inhibitory effect on allergen } \\
\text { challenge-induced nasal } \\
\text { mucosal swelling }\end{array}$ & [143] \\
\hline $\begin{array}{c}\text { Ramatroban (BYAu3405), oral } \\
\text { administration, } 150 \mathrm{mg} \text { twice daily for } \\
\text { four weeks }\end{array}$ & $\begin{array}{l}\text { Perianal allergic rhinitis } \\
\qquad(n=11)\end{array}$ & $\begin{array}{l}\text { Inhibitory effect on histamine-induced } \\
\text { nasal reactivity, decreased eosinophil } \\
\text { counts in nasal lavage fluid }\end{array}$ & [144] \\
\hline \multicolumn{4}{|l|}{ TP antagonist } \\
\hline $\begin{array}{l}\text { Seratrodast, oral administration, } \\
80 \mathrm{mg} \text { daily for four weeks }\end{array}$ & $\begin{array}{l}\text { Asthma } \\
(n=14)\end{array}$ & $\begin{array}{l}\text { Decreased airway } \\
\text { hyper-responsiveness, no definite effect } \\
\text { on exhaled nitric oxide and } \\
\text { sputum eosinophils }\end{array}$ & [145] \\
\hline $\begin{array}{l}\text { AA02414, oral administration, } \\
80 \text { mg daily for four months }\end{array}$ & $\begin{array}{l}\text { Asthma } \\
(n=31)\end{array}$ & $\begin{array}{l}\text { Improved symptom score, peak } \\
\text { expiratory flow, and bronchial } \\
\text { responsiveness to metacholine, } \\
\text { decreased activated } \\
\text { eosinophil infiltration }\end{array}$ & [146] \\
\hline \multicolumn{4}{|l|}{ DP1 antagonist } \\
\hline $\begin{array}{l}\text { ONO-4053, oral administration, } \\
300 \mathrm{mg} \text { daily for two weeks }\end{array}$ & $\begin{array}{l}\text { Seasonal allergic rhinitis } \\
\text { (Japanese cedar pollen) } \\
\qquad(n=200)\end{array}$ & $\begin{array}{l}\text { Greater improvement in nasal } \\
\text { symptoms compared to either } \\
\text { placebo or pranlukast }\end{array}$ & {$[147]$} \\
\hline \multicolumn{4}{|l|}{$\mathrm{PGI}_{2}$ analogue } \\
\hline $\begin{array}{l}\text { OP-41483, oral administration, } 200 \mu \mathrm{g} \\
4 \text { times daily for four weeks }\end{array}$ & $\begin{array}{l}\text { Stable asthma } \\
\qquad(n=8)\end{array}$ & $\begin{array}{l}\text { No direct effect on bronchial } \\
\text { responsiveness }\end{array}$ & [148] \\
\hline
\end{tabular}

$\mathrm{FEV}_{1}$ —one second-forced expiratory volume; FeNO—fractional exhaled nitric oxide.

\subsection{Asthma}

Numerous studies have focused on the clinical relevance of prostaglandins in asthma. In a study that examined concentrations of PG mediators from BAL fluid, both $\mathrm{PGD}_{2}$ and PGF2 $\alpha$ showed 12- and 20 -fold higher levels in asthmatic patients than nonallergic controls, respectively [149]. Another study reported that concentrations of $\mathrm{PGD}_{2}, \mathrm{TXB}_{2}$, and $\mathrm{PGI}_{2}$ metabolites was much higher (up to 208-fold) in BAL fluid $5 \mathrm{~min}$ after an allergen challenge in allergic asthmatic patients compared to the controls [150]. In addition, epithelial cells obtained from severely asthmatic patients showed higher levels of H-PGDS compared to controls, correlating with $\mathrm{PGD}_{2}$ levels. Furthermore, BAL fluid collected from severely asthmatic patients showed stronger expression of DP2 receptors than that from mild asthmatics or heathy controls; however, there was no difference in DP1 receptor expression among groups [151]. As for $\mathrm{PGE}_{2}$ levels, studies regarding their correlation with eosinophils reported that a lower sputum $\mathrm{PGE}_{2}$ level is associated with eosinophilia in asthmatic patients [152].

To date, numerous clinical trials have shown that DP2 antagonists are effective for patients with asthma (Figure 1) [153-155]. Fevipiprant (QAW039), an oral DP2 antagonist, improved pulmonary function in asthmatic patients with severely impaired lung functions and patients with uncontrolled asthma using an inhaled corticosteroid (ICS) $[132,133,156]$. In a single-center randomized controlled trial, decreased sputum eosinophil count was observed in patients with moderate to severe asthma after treatment with fevipiprant [134]. Indeed, to date, fevipiprant is recognized as the most potent pharmacologic agent targeting PG receptors $[157,158]$. All phase II studies have agreed on the safety and tolerability of fevipiprant [159]. Several phase III trials are ongoing to determine its potential to prevent asthma exacerbation (LUSTER1 \& LUSTER2), and its safety in moderate uncontrolled asthma in ICS-treated asthmatic patients (ZEAL1 \& ZEAL2) [160-164]. Another DP2 antagonist, ARRY-502, improved one second-forced expiratory volume $\left(\mathrm{FEV}_{1}\right)$ results as well as symptom-related quality of life of patients with asthma relative to control patients. This effect was greater in patients with elevated Th2-associated biomarkers [135]. Treatment with AZD1981, a DP2 receptor antagonist, showed 
improvements in the asthma control questionnaire score as well as $\mathrm{FEV}_{1}$ in patients with allergic asthma after four weeks [136]. OC000459 was also found to be safe and effective in inhibiting the DP2 receptor, showing significant improvements in pulmonary function in patients with eosinophil-dominant allergic asthma [137]. Other DP2 selective antagonists that were effective from phase II trials include GB001, BI671800, and setipiprant (ACT-129968) [139-141,165].

Recently, a phase I clinical trial for evaluating the efficacy of ZL-2010, an H-PGDS inhibitor, in asthma treatment has been completed, but the results are not yet published (Figure 1) [166].

In patients with asthma, $\mathrm{PGE}_{2}$ levels in sputum were negatively correlated with the eosinophil count, and inhaled $\mathrm{PGE}_{2}$ was effective in preventing pulmonary hyper-reactivity after an allergen challenge $[167,168]$, but inhaled $\mathrm{PGE}_{2}$ did not alter baseline pulmonary functions without this challenge [168]. For investigating the effects of oral $\mathrm{PGE}_{2}$ administration, a synthetic $\mathrm{PGE}_{2}$ analog named misoprostol was used, because of the short half-life of $\mathrm{PGE}_{2}$ (Figure 1) [169]. However, no protective effect of misoprostol on pulmonary function, asthma symptom scores, or serum eosinophil count was identified in patients with aspirin-sensitive asthma, suggesting that oral administration could not deliver a sufficient concentration to the pulmonary system for pharmacologic activation [169].

Although $\mathrm{PGF}_{2 \alpha}$ has not been studied as much as $\mathrm{PGD}_{2}$ or $\mathrm{PGE}_{2}$, studies of its effect on allergic reactions have shown that $\mathrm{PGF}_{2 \alpha}$ inhalation decreases specific airway conductance in a dose-related manner, and induces bronchoconstriction, which can shorten the recovery by $\mathrm{PGE}_{2}[125,170]$. In addition, inhaled $\mathrm{PGF}_{2 \alpha}$ decreased the exhaled nitric oxide (NO) level, although the clinical implications of this finding have not yet been identified [171].

The effects of allergic response treatment with $\mathrm{PGI}_{2}$ have been extensively studied; however, to our knowledge the most recent article was published in 1991 [172]. This might be because of the unstable nature of $\mathrm{PGI}_{2}$ that catalyzes within 3 to $5 \mathrm{~min}$, and the absence of a stable $\mathrm{PGI}_{2}$ analog. Previous studies have shown that $\mathrm{PGI}_{2}$ inhalation did not exert a protective effect against bronchoconstriction after an allergen challenge, with no change in airway conductance $[148,173]$. Moreover, another study using an oral analog of $\mathrm{PGI}_{2}$ (OP-41483), showed no effect on $\mathrm{FEV}_{1}$ and airway responsiveness in patients with asthma (Figure 1) [172]. However, the converse result has also been reported-that $\mathrm{PGI}_{2}$ inhalation causes a dose-dependent decrease in $\mathrm{FEV}_{1}$ with no effect on airway conductance, suggesting narrowing of the airway due to mucosal blood engorgement via the vasodilatory effects of $\mathrm{PGI}_{2}$ [174].

As for TXA ${ }_{2}$, treatment of patients with asthma using a TP antagonist, seratrodast (AA-2414), resulted in improvement of symptom scores, bronchial responsiveness, and peak expiratory flow, and a reduction of inflammatory biomarkers in the epithelium of patients after four weeks $[145,146]$.

\subsection{Allergic Rhinitis}

Clinical studies of allergic rhinitis have also suggested the importance of PGs in the disease. In nasal lavage fluid (NALF), the $\mathrm{PGD}_{2}$ level was higher in patients with allergic rhinitis compared to those with nonallergic rhinitis [175]. Nasal mucosa samples obtained from the turbinates of patients with allergic rhinitis revealed stronger DP2 expression in eosinophils, mast cells, T lymphocytes, and epithelial cells compared to the nonallergic nasal mucosa [176]. In patients with seasonal allergic rhinitis and sensitization to grass pollen, the $\mathrm{PGE}_{2}$ level in NALF decreased significantly during the pollen-exposure season, which was negatively correlated with nasal eosinophilia [177].

Although fewer than for asthma, several clinical trials of PG-targeting pharmacologic agents have been conducted for allergic rhinitis (Table 2). In a randomized, double-blind, placebo-controlled study, a DP2 antagonist (OC000459) was effective in reducing nasal and ocular symptoms in patients with allergic rhinitis caused by grass pollen [138]. Clinical trials of the dual DP2/TP receptor antagonist, ramatroban (BAY u3405), in patients with rhinitis showed conflicting results. In a study of patients with atrophic rhinitis, $\mathrm{PGD}_{2}$-induced nasal congestion was not relieved by the administration of a single 20-mg dose of ramatroban [178]. However, when administrated twice a day at a higher dose $(150 \mathrm{mg})$ for four weeks, it effectively decreased eosinophil levels in the nasal lavage fluid and reduced mucosal swelling after house dust challenges in patients with perennial allergic rhinitis $[143,144]$. 
In a phase II clinical study, setipiprant showed a significant improvement in nasal symptoms, during the day and night, in patients with seasonal allergic rhinitis; however, in the phase III trial it did not show efficacy at the endpoint [142]. The DP1 antagonist, ONO-4053, also reduced nasal symptoms including rhinorrhea, sneezing, and nasal itching in patients with seasonal allergic rhinitis, without causing safety issues, in a phase II trial [147].

Although previous studies have shown that selective inhibition of H-PGDS (TFC-007 and TAS-204) is effective in reducing nasal blockage and eosinophil infiltration in animal models of allergic rhinitis, no studies have yet been conducted in humans to determine the role of H-PGDS inhibitors in allergic rhinitis $[179,180]$.

\subsection{Aspirin-Exacerbated Respiratory Disease}

AERD is a nonallergic disease caused by dysregulation of eicosanoids and characterized by eosinophilia, Th2 dominant cytokines, and a marked increase of CysLTs [181]. In AERD patients, COX-2 expression and $\mathrm{PGE}_{2}$ level are significantly reduced, because the $m P G E S-1$ gene is functionally coupled to COX-2. However, there was no change in the expression of COX-1. Conversely, the 5-lipoxygenase (5-LO) pathway, which metabolizes AA into LTs, is markedly upregulated in these patients, resulting in an extremely high level of CysLTs, which activate mast cells and eosinophils $[10,182]$. Addition of nonsteroidal anti-inflammatory drugs, especially COX-1 inhibitors, forces AA metabolism towards LT synthesis and further decreases $\mathrm{PGE}_{2}$ production, resulting in the uncontrolled release of $\mathrm{LTC}_{4}, \mathrm{LTD}_{4}$, $\mathrm{LTE}_{4}$, and $\mathrm{PGD}_{2}$ by countering the suppressive effect of $\mathrm{PGE}_{2}$ on 5-LO [183-185].

Studies of the nasal mucosa or nasal polyps of patients with AERD have shown lower expression levels of the EP2 receptor than in healthy patients, or patients with aspirin tolerance, suggesting that the decreased expression of EP2 in AERD might have a synergistic effect on the anti-inflammatory and bronchoprotective capacity of the $\mathrm{PGE}_{2}-\mathrm{EP} 2$ axis $[186,187]$. Interference with $\mathrm{PGE}_{2}$ production by oral administration of the $\mathrm{PGE}_{2}$ analog misoprostol did not protect against the symptoms induced by NSAIDs in patients with AERD [188].

The importance of $\mathrm{PGD}_{2}$ in AERD pathogenesis has also been studied [189]. In patients with $\mathrm{AERD}$, an aspirin challenge did not reduce the $\mathrm{PGD}_{2}$ concentration in BAL fluid, unlike in patients with asthma $[190,191]$. Moreover, frequent aspirin challenges increased $\mathrm{PGD}_{2}$ metabolites in the urine and serum of patients with AERD, possibly owing to the abnormal activation of mast cells [192]. A study evaluating the role of $\mathrm{PGD}_{2}$ in AERD showed that severe extra-pulmonary reactions are associated with $\mathrm{PGD}_{2}$ production, and high-dose aspirin therapy could be used to inhibit $\mathrm{PGD}_{2}$ generation and suppress inflammatory cell recruitment [189]. In patients with AERD, intravenous injection of $\mathrm{PGI}_{2}$ had no effect in preventing decreased airflow after aspirin stimulation [193].

\subsection{Nasal Polyps}

Few studies have investigated PGs in nasal polyps, whereas comparatively more have assessed their roles in asthma or allergic rhinitis. However, the clinical relevance of PGs has been well demonstrated, even disregarding their association with aspirin sensitivity [194].

$\mathrm{PGE}_{2}$ concentrations and COX-2 mRNA expression were lower in nasal polyp tissues than in nasal mucosas, either from healthy controls or from patients with chronic rhinosinusitis without nasal polyps. Higher production of LT metabolites, such as $\mathrm{LTC}_{4}$, $\mathrm{LTD}_{4}$, and $\mathrm{LTE}_{4}$ was correlated with lower $\mathrm{PGE}_{2}$ concentrations [195]. Another study revealed a decreased level of $\mathrm{PGD}_{2}$ and its metabolites in the serum of patients with chronic rhinosinusitis [196]. Supporting this finding, the mRNA expression of PGDS and PGES was higher and lower, respectively, in nasal polyps than in the normal uncinate process, and a negative correlation was observed between the PGDS and PGES levels [197]. Moreover, the high PGDS and low PGES levels were correlated with increased eosinophil infiltration, as well as disease severity, suggesting that PGs might have a role in eosinophilic inflammation in nasal polyps [197]. 
Regarding the expression of individual $\mathrm{PGE}_{2}$ receptors in nasal polyps, the EP2 receptor showed a lower expression in immunohistochemistry of nasal biopsies from patients with both aspirin-sensitive and -tolerant chronic rhinosinusitis than controls. However, the expression was lowest in aspirin-sensitive patients $[198,199]$. Moreover, increased EP1 receptor expression was associated with the eosinophilic phenotype in patients with nasal polyps without aspirin intolerance [194]. In a recent study, exposure to cigarette smoking was related with diminished expression of EP2 and EP4 receptors in nasal polyps of patients with chronic rhinosinusitis, which might explain the severe inflammation caused by smoking [200]. In a study of $\mathrm{PGD}_{2}$ receptors in nasal polyp tissue, higher DP1 and lower DP2 receptor expression was identified relative to normal nasal mucosa, and both these findings correlated with increased levels of PGDS and eotaxin [201].

Despite the promising importance of PGs in nasal polyps reported by previous studies, to our knowledge, clinical trials for nasal polyps with pharmacologic agents modulating PGs have not yet been conducted, and future studies are required to provide clinical evidence.

\section{Conclusions}

In this review, we described the biosynthesis of PGs and their roles in various cell types relating to allergic airway inflammation. We summarized up-to-date information about the clinical relevance of PGs and clinical trials regulating their activation in each allergic airway disease. Owing to their short half-life, researchers have faced difficulties in conducting in vivo studies and clinical trials of PGs. However, with the development of stable PG analogs, their promising role in regulating allergic reactions, and the possibility for future therapeutic agents based on their biochemistry has been demonstrated by both animal and human studies. Nevertheless, little is known about their role in modulating the pathogenesis of nasal polyps, or the effect of PG synthase inhibitors on allergic inflammation. Future studies should focus on methods for maintaining the biological activity of PGs, and the development of pharmacological agents targeting PG synthase to assist in modulating allergic airway diseases, such as nasal polyps.

Author Contributions: All authors have read and agreed to the published version of the manuscript.

Funding: This research was supported by the Basic Science Research Program, National Research Foundation of Korea, funded by the Ministry of Science and Technology and the Ministry of Science, ICT \& Future Planning (2017R1A2B2003575), and the Korea Health Technology R\&D Project (HI17C0387), Korea Health Industry Development Institute (KHIDI), and the Ministry of Health \& Welfare. This research was also supported by a Korea University grant, and a grant from Korea University Medical Center as well as by Anam Hospital, Seoul, Republic of Korea (O1905011).

Conflicts of Interest: The authors declare no conflicts of interest.

\section{Abbreviations}

$\begin{array}{ll}\text { AA } & \text { arachidonic acid } \\ \text { AERD } & \text { aspirin exacerbated respiratory disease } \\ \text { cAMP } & \text { cyclic adenosine } 3^{\prime}, 5^{\prime} \text {-monophosphate } \\ \text { bAL } & \text { bronchoalveolar lavage } \\ \text { COX } & \text { cyclooxygenase } \\ \text { cPGES } & \text { cytosolic prostaglandin E synthase } \\ \text { cysLT } & \text { Cysteinyl leukotriene } \\ \text { DC } & \text { dendritic cell } \\ \text { FEV } & \text { forced expiratory volume 1 } \\ \text { H-PGDS } & \text { hematopoietic-prostaglandin D synthase } \\ \text { IgE } & \text { immunoglobulin E } \\ \text { IL } & \text { interleukin } \\ \text { ILC } & \text { innate lymphoid cell } \\ \text { INF- } \gamma & \text { interferon } \gamma \\ \text { L-PGDS } & \text { lipocalin-prostaglandin D synthase }\end{array}$




\begin{tabular}{|c|c|}
\hline LPS & lipopolysaccharide \\
\hline LT & leukotriene \\
\hline $\mathrm{LTC}_{4}$ & leukotriene $\mathrm{C}_{4}$ \\
\hline $\mathrm{LTD}_{4}$ & leukotriene $\mathrm{D}_{4}$ \\
\hline $\mathrm{LTE}_{4}$ & leukotriene $E_{4}$ \\
\hline mPGES & microsomal prostaglandin E synthase \\
\hline NALF & nasal lavage fluid \\
\hline NSAID & nonsteroidal anti-inflammatory drug \\
\hline PG & prostaglandin \\
\hline $\mathrm{PGD}_{2}$ & prostaglandin $\mathrm{D}_{2}$ \\
\hline $\mathrm{PGE}_{2}$ & prostaglandin $E_{2}$ \\
\hline $\mathrm{PGF}_{2 \alpha}$ & prostaglandin $\mathrm{F}_{2 \alpha}$ \\
\hline PGFS & prostaglandin F synthase \\
\hline $\mathrm{PGG}_{2}$ & prostaglandin $G_{2}$ \\
\hline $\mathrm{PGH}_{2}$ & prostaglandin $\mathrm{H}_{2}$ \\
\hline $\mathrm{PGI}_{2}$ & prostaglandin $\mathrm{I}_{2}$ \\
\hline $\mathrm{PLA}_{2}$ & phospholipase A2 \\
\hline TNF- $\alpha$ & tumor necrosis factor $\alpha$ \\
\hline Treg & regulatory $\mathrm{T}$ cell \\
\hline TSLP & thymic stromal lymphopoietin \\
\hline $\mathrm{TXA}_{2}$ & thromboxane $\mathrm{A}_{2}$ \\
\hline $\mathrm{TXB}_{2}$ & thromboxane $\mathrm{B}_{2}$ \\
\hline
\end{tabular}

\section{References}

1. Korbecki, J.; Baranowska-Bosiacka, I.; Gutowska, I.; Chlubek, D. Cyclooxygenase pathways. Acta Biochim. Pol. 2014, 61, 639-649. [CrossRef] [PubMed]

2. Debeuf, N.; Lambrecht, B.N. Eicosanoid Control Over Antigen Presenting Cells in Asthma. Front. Immunol. 2018, 9, 2006. [CrossRef] [PubMed]

3. Ricciotti, E.; FitzGerald, G.A. Prostaglandins and inflammation. Arter. Thromb Vasc. Biol. 2011, 31, $986-1000$. [CrossRef] [PubMed]

4. Piper, P.J.; Vane, J.R. Release of additional factors in anaphylaxis and its antagonism by anti-inflammatory drugs. Nature 1969, 223, 29-35. [CrossRef] [PubMed]

5. Claar, D.; Hartert, T.V.; Peebles, R.S., Jr. The role of prostaglandins in allergic lung inflammation and asthma. Expert Rev. Respir. Med. 2015, 9, 55-72. [CrossRef]

6. Nakayama, T. Introduction to "allergic inflammation". Immunol. Rev. 2017, 278, 5-7. [CrossRef]

7. Elieh Ali Komi, D.; Bjermer, L. Mast Cell-Mediated Orchestration of the Immune Responses in Human Allergic Asthma: Current Insights. Clin. Rev. Allergy Immunol. 2019, 56, 234-247. [CrossRef]

8. White, A.A.; Stevenson, D.D. Aspirin-Exacerbated Respiratory Disease. N. Engl. J. Med. 2018, 379, 1060-1070. [CrossRef]

9. Sanak, M. Eicosanoid Mediators in the Airway Inflammation of Asthmatic Patients: What is New? Allergy Asthma Immunol. Res. 2016, 8, 481-490. [CrossRef]

10. Laidlaw, T.M. Pathogenesis of NSAID-induced reactions in aspirin-exacerbated respiratory disease. World J. Otorhinolaryngol. Head Neck Surg. 2018, 4, 162-168. [CrossRef]

11. Dennis, E.A.; Cao, J.; Hsu, Y.H.; Magrioti, V.; Kokotos, G. Phospholipase A2 enzymes: Physical structure, biological function, disease implication, chemical inhibition, and therapeutic intervention. Chem. Rev. 2011, 111, 6130-6185. [CrossRef] [PubMed]

12. Murakami, M.; Kudo, I. Phospholipase A2. J. Biochem. 2002, 131, 285-292. [CrossRef] [PubMed]

13. Hallstrand, T.S.; Lai, Y.; Ni, Z.; Oslund, R.C.; Henderson, W.R., Jr.; Gelb, M.H.; Wenzel, S.E. Relationship between levels of secreted phospholipase A(2) groups IIA and $\mathrm{X}$ in the airways and asthma severity. Clin. Exp. Allergy J. Br. Soc. Allergy Clin. Immunol. 2011, 41, 801-810. [CrossRef] [PubMed]

14. Smith, W.L.; Urade, Y.; Jakobsson, P.J. Enzymes of the cyclooxygenase pathways of prostanoid biosynthesis. Chem. Rev. 2011, 111, 5821-5865. [CrossRef] [PubMed] 
15. Kang, Y.J.; Mbonye, U.R.; DeLong, C.J.; Wada, M.; Smith, W.L. Regulation of intracellular cyclooxygenase levels by gene transcription and protein degradation. Prog. Lipid Res. 2007, 46, 108-125. [CrossRef]

16. Hata, A.N.; Breyer, R.M. Pharmacology and signaling of prostaglandin receptors: Multiple roles in inflammation and immune modulation. Pharmacol. Ther. 2004, 103, 147-166. [CrossRef]

17. Narumiya, S.; FitzGerald, G.A. Genetic and pharmacological analysis of prostanoid receptor function. J. Clin. Investig. 2001, 108, 25-30. [CrossRef]

18. Seo, M.J.; Oh, D.K. Prostaglandin synthases: Molecular characterization and involvement in prostaglandin biosynthesis. Prog. Lipid Res. 2017, 66, 50-68. [CrossRef]

19. Lewis, R.A.; Soter, N.A.; Diamond, P.T.; Austen, K.F.; Oates, J.A.; Roberts, L.J., 2nd. Prostaglandin D2 generation after activation of rat and human mast cells with anti-IgE. J. Immunol. 1982, 129, 1627-1631.

20. Luna-Gomes, T.; Magalhaes, K.G.; Mesquita-Santos, F.P.; Bakker-Abreu, I.; Samico, R.F.; Molinaro, R.; Calheiros, A.S.; Diaz, B.L.; Bozza, P.T.; Weller, P.F.; et al. Eosinophils as a novel cell source of prostaglandin D2: Autocrine role in allergic inflammation. J. Immunol. 2011, 187, 6518-6526. [CrossRef]

21. Okano, M.; Fujiwara, T.; Sugata, Y.; Gotoh, D.; Masaoka, Y.; Sogo, M.; Tanimoto, W.; Yamamoto, M.; Matsumoto, R.; Eguchi, N.; et al. Presence and characterization of prostaglandin D2-related molecules in nasal mucosa of patients with allergic rhinitis. Am. J. Rhinol. 2006, 20, 342-348. [CrossRef] [PubMed]

22. Brightling, C.E.; Brusselle, G.; Altman, P. The impact of the prostaglandin D2 receptor 2 and its downstream effects on the pathophysiology of asthma. Allergy 2019. [CrossRef] [PubMed]

23. Serezani, C.H.; Ballinger, M.N.; Aronoff, D.M.; Peters-Golden, M. Cyclic AMP: Master regulator of innate immune cell function. Am. J. Respir. Cell Mol. Biol. 2008, 39, 127-132. [CrossRef] [PubMed]

24. Johnston, S.L.; Freezer, N.J.; Ritter, W.; O’Toole, S.; Howarth, P.H. Prostaglandin D2-induced bronchoconstriction is mediated only in part by the thromboxane prostanoid receptor. Eur. Respir. J. 1995, 8, 411-415. [CrossRef] [PubMed]

25. Murakami, M.; Nakashima, K.; Kamei, D.; Masuda, S.; Ishikawa, Y.; Ishii, T.; Ohmiya, Y.; Watanabe, K.; Kudo, I. Cellular prostaglandin E2 production by membrane-bound prostaglandin E synthase-2 via both cyclooxygenases-1 and -2. J. Biol. Chem. 2003, 278, 37937-37947. [CrossRef] [PubMed]

26. Betz, M.; Fox, B.S. Prostaglandin E2 inhibits production of Th1 lymphokines but not of Th2 lymphokines. J. Immunol. 1991, 146, 108-113.

27. Komoto, J.; Yamada, T.; Watanabe, K.; Woodward, D.F.; Takusagawa, F. Prostaglandin F2alpha formation from prostaglandin $\mathrm{H} 2$ by prostaglandin F synthase (PGFS): Crystal structure of PGFS containing bimatoprost. Biochemistry 2006, 45, 1987-1996. [CrossRef]

28. Nakayama, T. Prostacyclin analogues: Prevention of cardiovascular diseases. Cardiovasc. Hematol. Agents Med. Chem. 2006, 4, 351-359. [CrossRef]

29. Miyata, A.; Yokoyama, C.; Ihara, H.; Bandoh, S.; Takeda, O.; Takahashi, E.; Tanabe, T. Characterization of the human gene (TBXAS1) encoding thromboxane synthase. Eur. J. Biochem. 1994, 224, 273-279. [CrossRef]

30. Ruan, K.H. Advance in understanding the biosynthesis of prostacyclin and thromboxane A2 in the endoplasmic reticulum membrane via the cyclooxygenase pathway. Mini Rev. Med. Chem. 2004, 4, 639-647. [CrossRef]

31. Hirata, T.; Ushikubi, F.; Kakizuka, A.; Okuma, M.; Narumiya, S. Two thromboxane A2 receptor isoforms in human platelets. Opposite coupling to adenylyl cyclase with different sensitivity to Arg60 to Leu mutation. J. Clin. Investig. 1996, 97, 949-956. [CrossRef] [PubMed]

32. Wenzel, S.E. Emergence of Biomolecular Pathways to Define Novel Asthma Phenotypes. Type-2 Immunity and Beyond. Am. J. Respir. Cell Mol. Biol. 2016, 55, 1-4. [CrossRef] [PubMed]

33. Parulekar, A.D.; Kao, C.C.; Diamant, Z.; Hanania, N.A. Targeting the interleukin-4 and interleukin-13 pathways in severe asthma: Current knowledge and future needs. Curr. Opin. Pulm. Med. 2018, 24, 50-55. [CrossRef] [PubMed]

34. Karta, M.R.; Broide, D.H.; Doherty, T.A. Insights into Group 2 Innate Lymphoid Cells in Human Airway Disease. Curr. Allergy Asthma Rep. 2016, 16, 8. [CrossRef]

35. Samuchiwal, S.K.; Boyce, J.A. Role of lipid mediators and control of lymphocyte responses in type 2 immunopathology. J. Allergy Clin. Immunol. 2018, 141, 1182-1190. [CrossRef]

36. Choi, Y.H.; Lee, S.N.; Aoyagi, H.; Yamasaki, Y.; Yoo, J.Y.; Park, B.; Shin, D.M.; Yoon, H.G.; Yoon, J.H. The extracellular signal-regulated kinase mitogen-activated protein kinase/ribosomal S6 protein kinase 1 cascade phosphorylates cAMP response element-binding protein to induce MUC5B gene expression via D-prostanoid receptor signaling. J. Biol. Chem. 2011, 286, 34199-34214. [CrossRef] 
37. Wright, D.H.; Ford-Hutchinson, A.W.; Chadee, K.; Metters, K.M. The human prostanoid DP receptor stimulates mucin secretion in LS174T cells. Br. J. Pharm. 2000, 131, 1537-1545. [CrossRef]

38. Sally, E.S.; Yassine, A.; Christopher, E.B. D prostanoid receptor 2 (chemoattractant receptor-homologous molecule expressed on TH2 cells) protein expression in asthmatic patients and its effects on bronchial epithelial cells. J. Allergy Clin. Immunol. 2015, 135, 395-406.

39. Akaba, T.; Komiya, K.; Suzaki, I.; Kozaki, Y.; Tamaoki, J.; Rubin, B.K. Activating prostaglandin E2 receptor subtype EP4 increases secreted mucin from airway goblet cells. Pulm. Pharmacol. Ther. 2018, 48, 117-123. [CrossRef]

40. Kowalski, M.L.; Pawliczak, R.; Wozniak, J.; Siuda, K.; Poniatowska, M.; Iwaszkiewicz, J.; Kornatowski, T.; Kaliner, M.A. Differential metabolism of arachidonic acid in nasal polyp epithelial cells cultured from aspirin-sensitive and aspirin-tolerant patients. Am. J. Respir. Crit. Care Med. 2000, 161, 391-398. [CrossRef]

41. Schmidt, L.M.; Belvisi, M.G.; Bode, K.A.; Bauer, J.; Schmidt, C.; Suchy, M.T.; Tsikas, D.; Scheuerer, J.; Lasitschka, F.; Grone, H.J.; et al. Bronchial epithelial cell-derived prostaglandin E2 dampens the reactivity of dendritic cells. J. Immunol. 2011, 186, 2095-2105. [CrossRef] [PubMed]

42. Barnett, K.; Jacoby, D.B.; Nadel, J.A.; Lazarus, S.C. The effects of epithelial cell supernatant on contractions of isolated canine tracheal smooth muscle. Am. Rev. Respir. Dis. 1988, 138, 780-783. [CrossRef]

43. Scandella, E.; Men, Y.; Legler, D.F.; Gillessen, S.; Prikler, L.; Ludewig, B.; Groettrup, M. CCL19/CCL21-triggered signal transduction and migration of dendritic cells requires prostaglandin E2. Blood 2004, 103, 1595-1601. [CrossRef] [PubMed]

44. Harizi, H.; Grosset, C.; Gualde, N. Prostaglandin E2 modulates dendritic cell function via EP2 and EP4 receptor subtypes. J. Leukoc. Biol. 2003, 73, 756-763. [CrossRef] [PubMed]

45. Legler, D.F.; Krause, P.; Scandella, E.; Singer, E.; Groettrup, M. Prostaglandin E2 is generally required for human dendritic cell migration and exerts its effect via EP2 and EP4 receptors. J. Immunol. 2006, 176, 966-973. [CrossRef] [PubMed]

46. Hammad, H.; de Heer, H.J.; Soullie, T.; Hoogsteden, H.C.; Trottein, F.; Lambrecht, B.N. Prostaglandin D2 inhibits airway dendritic cell migration and function in steady state conditions by selective activation of the D prostanoid receptor 1. J. Immunol. 2003, 171, 3936-3940. [CrossRef]

47. Hammad, H.; Kool, M.; Soullie, T.; Narumiya, S.; Trottein, F.; Hoogsteden, H.C.; Lambrecht, B.N. Activation of the D prostanoid 1 receptor suppresses asthma by modulation of lung dendritic cell function and induction of regulatory T cells. J. Exp. Med. 2007, 204, 357-367. [CrossRef]

48. Idzko, M.; Hammad, H.; van Nimwegen, M.; Kool, M.; Vos, N.; Hoogsteden, H.C.; Lambrecht, B.N. Inhaled iloprost suppresses the cardinal features of asthma via inhibition of airway dendritic cell function. J. Clin. Investig. 2007, 117, 464-472. [CrossRef]

49. Zhou, W.; Hashimoto, K.; Goleniewska, K.; O’Neal, J.F.; Ji, S.; Blackwell, T.S.; Fitzgerald, G.A.; Egan, K.M.; Geraci, M.W.; Peebles, R.S., Jr. Prostaglandin I2 analogs inhibit proinflammatory cytokine production and T cell stimulatory function of dendritic cells. J. Immunol. 2007, 178, 702-710. [CrossRef]

50. Kalinski, P.; Hilkens, C.M.; Snijders, A.; Snijdewint, F.G.; Kapsenberg, M.L. Dendritic cells, obtained from peripheral blood precursors in the presence of PGE2, promote Th2 responses. Adv. Exp. Med. Biol. 1997, 417, 363-367. [CrossRef]

51. Kalinski, P.; Hilkens, C.M.; Snijders, A.; Snijdewint, F.G.; Kapsenberg, M.L. IL-12-deficient dendritic cells, generated in the presence of prostaglandin E2, promote type 2 cytokine production in maturing human naive T helper cells. J. Immunol. 1997, 159, 28-35. [PubMed]

52. Kalinski, P.; Schuitemaker, J.H.; Hilkens, C.M.; Kapsenberg, M.L. Prostaglandin E2 induces the final maturation of IL-12-deficient CD1a+CD83+ dendritic cells: The levels of IL-12 are determined during the final dendritic cell maturation and are resistant to further modulation. J. Immunol. 1998, 161, 2804-2809. [PubMed]

53. Walker, W.; Rotondo, D. Prostaglandin E2 is a potent regulator of interleukin-12- and interleukin-18-induced natural killer cell interferon-gamma synthesis. Immunology 2004, 111, 298-305. [CrossRef] [PubMed]

54. Kaisar, M.M.M.; Ritter, M.; Del Fresno, C.; Jonasdottir, H.S.; van der Ham, A.J.; Pelgrom, L.R.; Schramm, G.; Layland, L.E.; Sancho, D.; Prazeres da Costa, C.; et al. Dectin-1/2-induced autocrine PGE2 signaling licenses dendritic cells to prime Th2 responses. PloS Biol. 2018, 16, e2005504. [CrossRef] [PubMed] 
55. Harizi, H.; Norbert, G. Inhibition of IL-6, TNF-alpha, and cyclooxygenase-2 protein expression by prostaglandin E2-induced IL-10 in bone marrow-derived dendritic cells. Cell Immunol. 2004, 228, 99-109. [CrossRef] [PubMed]

56. Vassiliou, E.; Jing, H.; Ganea, D. Prostaglandin E2 inhibits TNF production in murine bone marrow-derived dendritic cells. Cell Immunol. 2003, 223, 120-132. [CrossRef]

57. Harizi, H.; Juzan, M.; Pitard, V.; Moreau, J.F.; Gualde, N. Cyclooxygenase-2-issued prostaglandin e(2) enhances the production of endogenous IL-10, which down-regulates dendritic cell functions. J. Immunol. 2002, 168, 2255-2263. [CrossRef]

58. Rieser, C.; Papesh, C.; Herold, M.; Bock, G.; Ramoner, R.; Klocker, H.; Bartsch, G.; Thurnher, M. Differential deactivation of human dendritic cells by endotoxin desensitization: Role of tumor necrosis factor-alpha and prostaglandin E2. Blood 1998, 91, 3112-3117. [CrossRef]

59. Rieser, C.; Bock, G.; Klocker, H.; Bartsch, G.; Thurnher, M. Prostaglandin E2 and tumor necrosis factor alpha cooperate to activate human dendritic cells: Synergistic activation of interleukin 12 production. J. Exp. Med. 1997, 186, 1603-1608. [CrossRef]

60. Chizzolini, C.; Chicheportiche, R.; Alvarez, M.; de Rham, C.; Roux-Lombard, P.; Ferrari-Lacraz, S.; Dayer, J.M. Prostaglandin E2 synergistically with interleukin-23 favors human Th17 expansion. Blood 2008, 112, 3696-3703. [CrossRef]

61. Wong, T.H.; Gau, R.J.; Chen, Y.F.; Shen, H.H.; Lin, C.T.; Chen, S.L.; Suen, J.L. Dendritic cells treated with a prostaglandin $\mathrm{I} 2$ analog, iloprost, promote antigen-specific regulatory $\mathrm{T}$ cell differentiation in mice. Int. Immunopharmacol. 2019, 79, 106106. [CrossRef]

62. Tanaka, K.; Hirai, H.; Takano, S.; Nakamura, M.; Nagata, K. Effects of prostaglandin D2 on helper T cell functions. Biochem. Biophys. Res. Commun. 2004, 316, 1009-1014. [CrossRef] [PubMed]

63. Mitson-Salazar, A.; Yin, Y.; Wansley, D.L.; Young, M.; Bolan, H.; Arceo, S.; Ho, N.; Koh, C.; Milner, J.D.; Stone, K.D.; et al. Hematopoietic prostaglandin D synthase defines a proeosinophilic pathogenic effector human $\mathrm{T}(\mathrm{H}) 2$ cell subpopulation with enhanced function. J. Allergy Clin. Immunol. 2016, 137, 907-918. [CrossRef]

64. Hilvering, B.; Hinks, T.S.C.; Stoger, L.; Marchi, E.; Salimi, M.; Shrimanker, R.; Liu, W.; Chen, W.; Luo, J.; Go, S.; et al. Synergistic activation of pro-inflammatory type-2 CD8(+) T lymphocytes by lipid mediators in severe eosinophilic asthma. Mucosal Immunol. 2018, 11, 1408-1419. [CrossRef] [PubMed]

65. Wambre, E.; Bajzik, V.; DeLong, J.H.; O’Brien, K.; Nguyen, Q.A.; Speake, C.; Gersuk, V.H.; DeBerg, H.A.; Whalen, E.; Ni, C.; et al. A phenotypically and functionally distinct human TH2 cell subpopulation is associated with allergic disorders. Sci. Transl. Med. 2017, 9. [CrossRef]

66. Palikhe, N.S.; Laratta, C.; Nahirney, D.; Vethanayagam, D.; Bhutani, M.; Vliagoftis, H.; Cameron, L. Elevated levels of circulating CD4(+) CRTh2(+) T cells characterize severe asthma. Clin. Exp. Allergy J. Br. Soc. Allergy Clin. Immunol. 2016, 46, 825-836. [CrossRef]

67. Shrestha Palikhe, N.; Bosonea, A.M.; Laratta, C.; Gandhi, V.D.; Nahirney, D.; Hillaby, A.; Bowen, M.; Bhutani, M.; Mayers, I.; Cameron, L.; et al. Stability of peripheral blood immune markers in patients with asthma. Allergy Asthma Clin. Immunol. 2019, 15, 30. [CrossRef]

68. Snijdewint, F.G.; Kalinski, P.; Wierenga, E.A.; Bos, J.D.; Kapsenberg, M.L. Prostaglandin E2 differentially modulates cytokine secretion profiles of human T helper lymphocytes. J. Immunol. 1993, 150, 5321-5329.

69. Bao, Y.S.; Zhang, P.; Xie, R.J.; Wang, M.; Wang, Z.Y.; Zhou, Z.; Zhai, W.J.; Feng, S.Z.; Han, M.Z. The regulation of CD4+ T cell immune responses toward Th2 cell development by prostaglandin E2. Int. Immunopharmacol. 2011, 11, 1599-1605. [CrossRef]

70. Yao, C.; Hirata, T.; Soontrapa, K.; Ma, X.; Takemori, H.; Narumiya, S. Prostaglandin E(2) promotes Th1 differentiation via synergistic amplification of IL-12 signalling by cAMP and PI3-kinase. Nat. Commun. 2013, 4, 1685. [CrossRef]

71. Zaslona, Z.; Okunishi, K.; Bourdonnay, E.; Domingo-Gonzalez, R.; Moore, B.B.; Lukacs, N.W.; Aronoff, D.M.; Peters-Golden, M. Prostaglandin E(2) suppresses allergic sensitization and lung inflammation by targeting the E prostanoid 2 receptor on T cells. J. Allergy Clin. Immunol. 2014, 133, 379-387. [CrossRef] [PubMed]

72. Yao, C.; Sakata, D.; Esaki, Y.; Li, Y.; Matsuoka, T.; Kuroiwa, K.; Sugimoto, Y.; Narumiya, S. Prostaglandin E2-EP4 signaling promotes immune inflammation through Th1 cell differentiation and Th17 cell expansion. Nat. Med. 2009, 15, 633-640. [CrossRef] [PubMed] 
73. Lee, J.; Aoki, T.; Thumkeo, D.; Siriwach, R.; Yao, C.; Narumiya, S. T cell-intrinsic prostaglandin E2-EP2/EP4 signaling is critical in pathogenic TH17 cell-driven inflammation. J. Allergy Clin. Immunol. 2019, 143, 631-643. [CrossRef] [PubMed]

74. Li, L.; Guan, K.; Zhou, Y.; Wu, J.; Wang, Y.; Wang, W. Prostaglandin E2 signal inhibits T regulatory cell differentiation during allergic rhinitis inflammation through EP4 receptor. World Allergy Organ. J. 2019, 12, 100090. [CrossRef]

75. Kawahara, K.; Hohjoh, H.; Inazumi, T.; Tsuchiya, S.; Sugimoto, Y. Prostaglandin E2-induced inflammation: Relevance of prostaglandin E receptors. Biochim. Biophys. Acta 2015, 1851, 414-421. [CrossRef]

76. Gao, Y.; Zhao, C.; Wang, W.; Jin, R.; Li, Q.; Ge, Q.; Guan, Y.; Zhang, Y. Prostaglandins E2 signal mediated by receptor subtype EP2 promotes IgE production in vivo and contributes to asthma development. Sci. Rep. 2016, 6, 20505. [CrossRef]

77. Roper, R.L.; Conrad, D.H.; Brown, D.M.; Warner, G.L.; Phipps, R.P. Prostaglandin E2 promotes IL-4-induced IgE and IgG1 synthesis. J. Immunol. 1990, 145, 2644-2651.

78. Fedyk, E.R.; Phipps, R.P. Prostaglandin E2 receptors of the EP2 and EP4 subtypes regulate activation and differentiation of mouse B lymphocytes to IgE-secreting cells. Proc. Natl. Acad. Sci. USA 1996, 93, 10978-10983. [CrossRef]

79. Barnig, C.; Cernadas, M.; Dutile, S.; Liu, X.; Perrella, M.A.; Kazani, S.; Wechsler, M.E.; Israel, E.; Levy, B.D. Lipoxin A4 regulates natural killer cell and type 2 innate lymphoid cell activation in asthma. Sci. Transl. Med. 2013, 5, 174ra126. [CrossRef]

80. Tojima, I.; Matsumoto, K.; Kikuoka, H.; Hara, S.; Yamamoto, S.; Shimizu, S.; Kouzaki, H.; Shimizu, T. Evidence for the induction of Th2 inflammation by group 2 innate lymphoid cells in response to prostaglandin D2 and cysteinyl leukotrienes in allergic rhinitis. Allergy 2019, 74, 2417-2426. [CrossRef]

81. Xue, L.; Salimi, M.; Panse, I.; Mjosberg, J.M.; McKenzie, A.N.; Spits, H.; Klenerman, P.; Ogg, G. Prostaglandin D2 activates group 2 innate lymphoid cells through chemoattractant receptor-homologous molecule expressed on TH2 cells. J. Allergy Clin. Immunol. 2014, 133, 1184-1194. [CrossRef] [PubMed]

82. Oyesola, O.O.; Duque, C.; Huang, L.C.; Larson, E.M.; Fruh, S.P.; Webb, L.M.; Peng, S.A.; Tait Wojno, E.D. The Prostaglandin D2 Receptor CRTH2 Promotes IL-33-Induced ILC2 Accumulation in the Lung. J. Immunol. 2020. [CrossRef] [PubMed]

83. Chen, R.; Smith, S.G.; Salter, B.; El-Gammal, A.; Oliveria, J.P.; Obminski, C.; Watson, R.; O’Byrne, P.M.; Gauvreau, G.M.; Sehmi, R. Allergen-induced Increases in Sputum Levels of Group 2 Innate Lymphoid Cells in Subjects with Asthma. Am. J. Respir. Crit. Care Med. 2017, 196, 700-712. [CrossRef] [PubMed]

84. Winkler, C.; Hochdorfer, T.; Israelsson, E.; Hasselberg, A.; Cavallin, A.; Thorn, K.; Muthas, D.; Shojaee, S.; Luer, K.; Muller, M.; et al. Activation of group 2 innate lymphoid cells after allergen challenge in asthmatic patients. J. Allergy Clin. Immunol. 2019, 144, 61-69. [CrossRef] [PubMed]

85. Eastman, J.J.; Cavagnero, K.J.; Deconde, A.S.; Kim, A.S.; Karta, M.R.; Broide, D.H.; Zuraw, B.L.; White, A.A.; Christiansen, S.C.; Doherty, T.A. Group 2 innate lymphoid cells are recruited to the nasal mucosa in patients with aspirin-exacerbated respiratory disease. J. Allergy Clin. Immunol. 2017, 140, 101-108. [CrossRef] [PubMed]

86. Hardman, C.; Chen, W.; Luo, J.; Batty, P.; Chen, Y.L.; Nahler, J.; Wu, Y.; Pavord, I.D.; Erpenbeck, V.J.; Sandham, D.A.; et al. Fevipiprant, a selective prostaglandin D2 receptor 2 antagonist, inhibits human group 2 innate lymphoid cell aggregation and function. J. Allergy Clin. Immunol. 2019, 143, 2329-2333. [CrossRef]

87. Maric, J.; Ravindran, A.; Mazzurana, L.; Van Acker, A.; Rao, A.; Kokkinou, E.; Ekoff, M.; Thomas, D.; Fauland, A.; Nilsson, G.; et al. Cytokine-induced endogenous production of prostaglandin D2 is essential for human group 2 innate lymphoid cell activation. J. Allergy Clin. Immunol. 2019, 143, 2202-2214. [CrossRef]

88. Maric, J.; Ravindran, A.; Mazzurana, L.; Bjorklund, A.K.; Van Acker, A.; Rao, A.; Friberg, D.; Dahlen, S.E.; Heinemann, A.; Konya, V.; et al. Prostaglandin E2 suppresses human group 2 innate lymphoid cell function. J. Allergy Clin. Immunol. 2018, 141, 1761-1773. [CrossRef]

89. Zhou, Y.; Wang, W.; Zhao, C.; Wang, Y.; Wu, H.; Sun, X.; Guan, Y.; Zhang, Y. Prostaglandin E2 Inhibits Group 2 Innate Lymphoid Cell Activation and Allergic Airway Inflammation Through E-Prostanoid 4-Cyclic Adenosine Monophosphate Signaling. Front. Immunol. 2018, 9, 501. [CrossRef]

90. Zhou, W.; Toki, S.; Zhang, J.; Goleniewksa, K.; Newcomb, D.C.; Cephus, J.Y.; Dulek, D.E.; Bloodworth, M.H.; Stier, M.T.; Polosuhkin, V.; et al. Prostaglandin I2 Signaling and Inhibition of Group 2 Innate Lymphoid Cell Responses. Am. J. Respir. Crit. Care Med. 2016, 193, 31-42. [CrossRef] 
91. Peinhaupt, M.; Sturm, E.M.; Heinemann, A. Prostaglandins and Their Receptors in Eosinophil Function and As Therapeutic Targets. Front. Med. (Lausanne) 2017, 4, 104. [CrossRef] [PubMed]

92. Sedej, M.; Schroder, R.; Bell, K.; Platzer, W.; Vukoja, A.; Kostenis, E.; Heinemann, A.; Waldhoer, M. D-type prostanoid receptor enhances the signaling of chemoattractant receptor-homologous molecule expressed on $\mathrm{T}(\mathrm{H}) 2$ cells. J. Allergy Clin. Immunol. 2012, 129, 492-500. [CrossRef] [PubMed]

93. Ueki, S.; Adachi, T.; Bourdeaux, J.; Oyamada, H.; Yamada, Y.; Hamada, K.; Kanda, A.; Kayaba, H.; Chihara, J. Expression of PPARgamma in eosinophils and its functional role in survival and chemotaxis. Immunol. Lett. 2003, 86, 183-189. [CrossRef]

94. Gervais, F.G.; Cruz, R.P.; Chateauneuf, A.; Gale, S.; Sawyer, N.; Nantel, F.; Metters, K.M.; O’Neill G, P. Selective modulation of chemokinesis, degranulation, and apoptosis in eosinophils through the PGD2 receptors CRTH2 and DP. J. Allergy Clin. Immunol. 2001, 108, 982-988. [CrossRef] [PubMed]

95. Monneret, G.; Gravel, S.; Diamond, M.; Rokach, J.; Powell, W.S. Prostaglandin D2 is a potent chemoattractant for human eosinophils that acts via a novel DP receptor. Blood 2001, 98, 1942-1948. [CrossRef]

96. Shamri, R.; Dubois, G.; Erpenbeck, V.J.; Mankuta, D.; Sandham, D.A.; Levi-Schaffer, F. Fevipiprant, a DP2 receptor antagonist, inhibits eosinophil migration towards mast cells. Clin. Exp. Allergy J. Br. Soc. Allergy Clin. Immunol. 2019, 49, 255-257. [CrossRef]

97. Heinemann, A.; Schuligoi, R.; Sabroe, I.; Hartnell, A.; Peskar, B.A. Delta 12-prostaglandin J2, a plasma metabolite of prostaglandin D2, causes eosinophil mobilization from the bone marrow and primes eosinophils for chemotaxis. J. Immunol. 2003, 170, 4752-4758. [CrossRef]

98. Schratl, P.; Sturm, E.M.; Royer, J.F.; Sturm, G.J.; Lippe, I.T.; Peskar, B.A.; Heinemann, A. Hierarchy of eosinophil chemoattractants: Role of p38 mitogen-activated protein kinase. Eur J. Immunol. 2006, 36, 2401-2409. [CrossRef]

99. Schratl, P.; Royer, J.F.; Kostenis, E.; Ulven, T.; Sturm, E.M.; Waldhoer, M.; Hoefler, G.; Schuligoi, R.; Lippe, I.T.; Peskar, B.A.; et al. The role of the prostaglandin D2 receptor, DP, in eosinophil trafficking. J. Immunol. 2007, 179, 4792-4799. [CrossRef]

100. Mesquita-Santos, F.P.; Bakker-Abreu, I.; Luna-Gomes, T.; Bozza, P.T.; Diaz, B.L.; Bandeira-Melo, C. Co-operative signalling through $\mathrm{DP}(1)$ and $\mathrm{DP}(2)$ prostanoid receptors is required to enhance leukotriene $\mathrm{C}(4)$ synthesis induced by prostaglandin $\mathrm{D}(2)$ in eosinophils. Br. J. Pharm. 2011, 162, 1674-1685. [CrossRef]

101. Feng, X.; Ramsden, M.K.; Negri, J.; Baker, M.G.; Payne, S.C.; Borish, L.; Steinke, J.W. Eosinophil production of prostaglandin D2 in patients with aspirin-exacerbated respiratory disease. J. Allergy Clin. Immunol. 2016, 138, 1089-1097. [CrossRef]

102. Teixeira, M.M.; al-Rashed, S.; Rossi, A.G.; Hellewell, P.G. Characterization of the prostanoid receptors mediating inhibition of PAF-induced aggregation of guinea-pig eosinophils. Br. J. Pharm. 1997, 121, 77-82. [CrossRef]

103. Butchers, P.R.; Vardey, C.J. The effect of prostanoids on the function of human eosinophils. Agents Actions Suppl. 1990, 31, 103-112. [CrossRef]

104. Luschnig-Schratl, P.; Sturm, E.M.; Konya, V.; Philipose, S.; Marsche, G.; Frohlich, E.; Samberger, C.; Lang-Loidolt, D.; Gattenlohner, S.; Lippe, I.T.; et al. EP4 receptor stimulation down-regulates human eosinophil function. Cell Mol. Life Sci. 2011, 68, 3573-3587. [CrossRef]

105. Sturm, E.M.; Schratl, P.; Schuligoi, R.; Konya, V.; Sturm, G.J.; Lippe, I.T.; Peskar, B.A.; Heinemann, A. Prostaglandin E2 inhibits eosinophil trafficking through E-prostanoid 2 receptors. J. Immunol. 2008, 181, 7273-7283. [CrossRef]

106. Peacock, C.D.; Misso, N.L.; Watkins, D.N.; Thompson, P.J. PGE 2 and dibutyryl cyclic adenosine monophosphate prolong eosinophil survival in vitro. J. Allergy Clin. Immunol. 1999, 104, 153-162. [CrossRef]

107. Konya, V.; Philipose, S.; Balint, Z.; Olschewski, A.; Marsche, G.; Sturm, E.M.; Schicho, R.; Peskar, B.A.; Schuligoi, R.; Heinemann, A. Interaction of eosinophils with endothelial cells is modulated by prostaglandin EP4 receptors. Eur J. Immunol. 2011, 41, 2379-2389. [CrossRef]

108. Pal, K.; Ramsden, M.; Shim, Y.M.; Borish, L.; Payne, S.C.; Steinke, J.W. Suppression of aspirin-mediated eosinophil activation by prostaglandin E2: Relevance to aspirin and nonsteroidal anti-inflammatory drug hypersensitivity. Ann. Allergy Asthma Immunol. 2019, 123, 503-506. [CrossRef]

109. Sturm, E.M.; Schuligoi, R.; Konya, V.; Sturm, G.J.; Heinemann, A. Inhibitory effect of prostaglandin I2 on bone marrow kinetics of eosinophils in the guinea pig. J. Leukoc. Biol. 2011, 90, 285-291. [CrossRef] 
110. Konya, V.; Sturm, E.M.; Schratl, P.; Beubler, E.; Marsche, G.; Schuligoi, R.; Lippe, I.T.; Peskar, B.A.; Heinemann, A. Endothelium-derived prostaglandin I(2) controls the migration of eosinophils. J. Allergy Clin. Immunol. 2010, 125, 1105-1113. [CrossRef]

111. Baothman, B.K.; Smith, J.; Kay, L.J.; Suvarna, S.K.; Peachell, P.T. Prostaglandin D2 generation from human lung mast cells is catalysed exclusively by cyclooxygenase-1. Eur. J. Pharm. 2018, 819, 225-232. [CrossRef] [PubMed]

112. Buchheit, K.M.; Cahill, K.N.; Katz, H.R.; Murphy, K.C.; Feng, C.; Lee-Sarwar, K.; Lai, J.; Bhattacharyya, N.; Israel, E.; Boyce, J.A.; et al. Thymic stromal lymphopoietin controls prostaglandin D2 generation in patients with aspirin-exacerbated respiratory disease. J. Allergy Clin. Immunol. 2016, 137, 1566-1576. [CrossRef] [PubMed]

113. Moon, T.C.; Campos-Alberto, E.; Yoshimura, T.; Bredo, G.; Rieger, A.M.; Puttagunta, L.; Barreda, D.R.; Befus, A.D.; Cameron, L. Expression of DP2 (CRTh2), a prostaglandin D(2) receptor, in human mast cells. PLoS ONE 2014, 9, e108595. [CrossRef] [PubMed]

114. Xia, J.; Abdu, S.; Maguire, T.J.A.; Hopkins, C.; Till, S.J.; Woszczek, G. Prostaglandin D2 receptors in human mast cells. Allergy 2019. [CrossRef]

115. Feng, C.; Beller, E.M.; Bagga, S.; Boyce, J.A. Human mast cells express multiple EP receptors for prostaglandin E2 that differentially modulate activation responses. Blood 2006, 107, 3243-3250. [CrossRef] [PubMed]

116. Kay, L.J.; Yeo, W.W.; Peachell, P.T. Prostaglandin E2 activates EP2 receptors to inhibit human lung mast cell degranulation. Br. J. Pharm. 2006, 147, 707-713. [CrossRef]

117. Torres, R.; Picado, C.; de Mora, F. The PGE2-EP2-mast cell axis: An antiasthma mechanism. Mol. Immunol. 2015, 63, 61-68. [CrossRef]

118. Bradbury, D.; Clarke, D.; Seedhouse, C.; Corbett, L.; Stocks, J.; Knox, A. Vascular endothelial growth factor induction by prostaglandin E2 in human airway smooth muscle cells is mediated by E prostanoid EP2/EP4 receptors and SP-1 transcription factor binding sites. J. Biol. Chem. 2005, 280, 29993-30000. [CrossRef]

119. Pavord, I.D.; Wong, C.S.; Williams, J.; Tattersfield, A.E. Effect of inhaled prostaglandin E2 on allergen-induced asthma. Am. Rev. Respir. Dis. 1993, 148, 87-90. [CrossRef]

120. Benyahia, C.; Gomez, I.; Kanyinda, L.; Boukais, K.; Danel, C.; Leseche, G.; Longrois, D.; Norel, X. PGE(2) receptor (EP(4)) agonists: Potent dilators of human bronchi and future asthma therapy? Pulm. Pharmacol. Ther. 2012, 25, 115-118. [CrossRef]

121. Buckley, J.; Birrell, M.A.; Maher, S.A.; Nials, A.T.; Clarke, D.L.; Belvisi, M.G. EP4 receptor as a new target for bronchodilator therapy. Thorax 2011, 66, 1029-1035. [CrossRef] [PubMed]

122. Lazzeri, N.; Belvisi, M.G.; Patel, H.J.; Yacoub, M.H.; Chung, K.F.; Mitchell, J.A. Effects of prostaglandin E2 and cAMP elevating drugs on GM-CSF release by cultured human airway smooth muscle cells. Relevance to asthma therapy. Am. J. Respir. Cell Mol. Biol. 2001, 24, 44-48. [CrossRef] [PubMed]

123. Aso, H.; Ito, S.; Mori, A.; Suganuma, N.; Morioka, M.; Takahara, N.; Kondo, M.; Hasegawa, Y. Differential regulation of airway smooth muscle cell migration by E-prostanoid receptor subtypes. Am. J. Respir. Cell Mol. Biol. 2013, 48, 322-329. [CrossRef] [PubMed]

124. Saunders, R.; Kaul, H.; Berair, R.; Gonem, S.; Singapuri, A.; Sutcliffe, A.J.; Chachi, L.; Biddle, M.S.; Kaur, D.; Bourne, M.; et al. DP2 antagonism reduces airway smooth muscle mass in asthma by decreasing eosinophilia and myofibroblast recruitment. Sci. Transl. Med. 2019, 11. [CrossRef]

125. Smith, A.P.; Cuthbert, M.F.; Dunlop, L.S. Effects of inhaled prostaglandins E1, E2, and F2alpha on the airway resistance of healthy and asthmatic man. Clin. Sci. Mol. Med. 1975, 48, 421-430. [CrossRef] [PubMed]

126. Davi, G.; Basili, S.; Vieri, M.; Cipollone, F.; Santarone, S.; Alessandri, C.; Gazzaniga, P.; Cordova, C.; Violi, F. Enhanced thromboxane biosynthesis in patients with chronic obstructive pulmonary disease. The Chronic Obstructive Bronchitis and Haemostasis Study Group. Am. J. Respir. Crit. Care Med. 1997, 156, 1794-1799. [CrossRef] [PubMed]

127. Lei, Y.; Cao, Y.; Zhang, Y.; Edvinsson, L.; Xu, C.B. Enhanced airway smooth muscle cell thromboxane receptor signaling via activation of JNK MAPK and extracellular calcium influx. Eur J. Pharm. 2011, 650, 629-638. [CrossRef]

128. Han, D.Y.; Cho, J.S.; Moon, Y.M.; Lee, H.R.; Lee, H.M.; Lee, B.D.; Baek, B.J. Effect of prostaglandin e2 on vascular endothelial growth factor production in nasal polyp fibroblasts. Allergy Asthma Immunol. Res. 2013, 5, 224-231. [CrossRef]

129. Roca-Ferrer, J.; Garcia-Garcia, F.J.; Pereda, J.; Perez-Gonzalez, M.; Pujols, L.; Alobid, I.; Mullol, J.; Picado, C. Reduced expression of COXs and production of prostaglandin $\mathrm{E}(2)$ in patients with nasal polyps with or without aspirin-intolerant asthma. J. Allergy Clin. Immunol. 2011, 128, 66-72. [CrossRef] 
130. Cahill, K.N.; Raby, B.A.; Zhou, X.; Guo, F.; Thibault, D.; Baccarelli, A.; Byun, H.M.; Bhattacharyya, N.; Steinke, J.W.; Boyce, J.A.; et al. Impaired E Prostanoid2 Expression and Resistance to Prostaglandin E2 in Nasal Polyp Fibroblasts from Subjects with Aspirin-Exacerbated Respiratory Disease. Am. J. Respir. Cell Mol. Biol. 2016, 54, 34-40. [CrossRef]

131. Kanai, K.; Okano, M.; Fujiwara, T.; Kariya, S.; Haruna, T.; Omichi, R.; Makihara, S.I.; Hirata, Y.; Nishizaki, K. Effect of prostaglandin D2 on VEGF release by nasal polyp fibroblasts. Allergol. Int. 2016, 65, 414-419. [CrossRef] [PubMed]

132. Erpenbeck, V.J.; Popov, T.A.; Miller, D.; Weinstein, S.F.; Spector, S.; Magnusson, B.; Osuntokun, W.; Goldsmith, P.; Weiss, M.; Beier, J. The oral CRTh2 antagonist QAW039 (fevipiprant): A phase II study in uncontrolled allergic asthma. Pulm. Pharmacol. Ther. 2016, 39, 54-63. [CrossRef] [PubMed]

133. Bateman, E.D.; Guerreros, A.G.; Brockhaus, F.; Holzhauer, B.; Pethe, A.; Kay, R.A.; Townley, R.G. Fevipiprant, an oral prostaglandin DP2 receptor (CRTh2) antagonist, in allergic asthma uncontrolled on low-dose inhaled corticosteroids. Eur. Respir. J. 2017, 50. [CrossRef]

134. Gonem, S.; Berair, R.; Singapuri, A.; Hartley, R.; Laurencin, M.F.M.; Bacher, G.; Holzhauer, B.; Bourne, M.; Mistry, V.; Pavord, I.D.; et al. Fevipiprant, a prostaglandin D2 receptor 2 antagonist, in patients with persistent eosinophilic asthma: A single-centre, randomised, double-blind, parallel-group, placebo-controlled trial. Lancet Respir. Med. 2016, 4, 699-707. [CrossRef]

135. Wenzel, S.; Chantry, D.; Eberhardt, C.; Hopkins, R.; Saunders, M.; Anderson, L.; Aitchinson, R.; Bell, S.; Izuhara, K.; Ono, J.; et al. ARRY-502, a potent, selective, oral CRTh2 antagonist reduces Th2 mediators in patients with mild to moderate Th2-driven asthma. Eur. Respir. J. 2014, 44, 4836.

136. Kuna, P.; Bjermer, L.; Tornling, G. Two Phase II randomized trials on the CRTh2 antagonist AZD1981 in adults with asthma. Drug Des. Dev. Ther. 2016, 10, 2759-2770. [CrossRef]

137. Pettipher, R.; Hunter, M.G.; Perkins, C.M.; Collins, L.P.; Lewis, T.; Baillet, M.; Steiner, J.; Bell, J.; Payton, M.A. Heightened response of eosinophilic asthmatic patients to the CRTH2 antagonist OC000459. Allergy 2014, 69, 1223-1232. [CrossRef]

138. Horak, F.; Zieglmayer, P.; Zieglmayer, R.; Lemell, P.; Collins, L.P.; Hunter, M.G.; Steiner, J.; Lewis, T.; Payton, M.A.; Perkins, C.M.; et al. The CRTH2 antagonist OC000459 reduces nasal and ocular symptoms in allergic subjects exposed to grass pollen, a randomised, placebo-controlled, double-blind trial. Allergy 2012, 67, 1572-1579. [CrossRef]

139. Ortega, H.; Fitzgerald, M.; Raghupathi, K.; Tompkins, C.A.; Shen, J.; Dittrich, K.; Pattwell, C.; Singh, D. A phase 2 study to evaluate the safety, efficacy and pharmacokinetics of DP2 antagonist GB001 and to explore biomarkers of airway inflammation in mild-to-moderate asthma. Clin. Exp. Allergy J. Br. Soc. Allergy Clin. Immunol. 2019. [CrossRef]

140. Hall, I.P.; Fowler, A.V.; Gupta, A.; Tetzlaff, K.; Nivens, M.C.; Sarno, M.; Finnigan, H.A.; Bateman, E.D.; Rand Sutherland, E. Efficacy of BI 671800, an oral CRTH2 antagonist, in poorly controlled asthma as sole controller and in the presence of inhaled corticosteroid treatment. Pulm. Pharmacol. Ther. 2015, 32, 37-44. [CrossRef]

141. Diamant, Z.; Sidharta, P.N.; Singh, D.; O'Connor, B.J.; Zuiker, R.; Leaker, B.R.; Silkey, M.; Dingemanse, J. Setipiprant, a selective CRTH2 antagonist, reduces allergen-induced airway responses in allergic asthmatics. Clin. Exp. Allergy J. Br. Soc. Allergy Clin. Immunol. 2014, 44, 1044-1052. [CrossRef] [PubMed]

142. Ratner, P.; Andrews, C.P.; Hampel, F.C.; Martin, B.; Mohar, D.E.; Bourrelly, D.; Danaietash, P.; Mangialaio, S.; Dingemanse, J.; Hmissi, A.; et al. Efficacy and safety of setipiprant in seasonal allergic rhinitis: Results from Phase 2 and Phase 3 randomized, double-blind, placebo- and active-referenced studies. Allergy Asthma Clin. Immunol. 2017, 13, 18. [CrossRef]

143. Terada, N.; Yamakoshi, T.; Hasegawa, M.; Tanikawa, H.; Maesako, K.; Ishikawa, K.; Konno, A. The effect of ramatroban (BAY u 3405), a thromboxane A2 receptor antagonist, on nasal cavity volume and minimum cross-sectional area and nasal mucosal hemodynamics after nasal mucosal allergen challenge in patients with perennial allergic rhinitis. Acta Otolaryngol. Suppl. 1998, 537, 32-37. [CrossRef] [PubMed]

144. Terada, N.; Yamakoshi, T.; Hasegawa, M.; Tanikawa, H.; Nagata, H.; Maesako, K.-i.; Konno, A. Effect of a thromboxane A2 receptor antagonist ramatroban (BAY u 3405), on inflammatory cells, chemical mediators and non-specific nasal hyperreactivity after allergen challenge in patients with perennial allergic rhinitis. Allergol. Int. 1998, 47, 59-67. [CrossRef] 
145. Aizawa, H.; Inoue, H.; Nakano, H.; Matsumoto, K.; Yoshida, M.; Fukuyama, S.; Koto, H.; Hara, N. Effects of thromboxane A2 antagonist on airway hyperresponsiveness, exhaled nitric oxide, and induced sputum eosinophils in asthmatics. Prostaglandins Leukot Essent Fat. Acids 1998, 59, 185-190. [CrossRef]

146. Hoshino, M.; Sim, J.; Shimizu, K.; Nakayama, H.; Koya, A. Effect of AA-2414, a thromboxane A2 receptor antagonist, on airway inflammation in subjects with asthma. J. Allergy Clin. Immunol. 1999, 103, 1054-1061. [CrossRef]

147. Okubo, K.; Hashiguchi, K.; Takeda, T.; Baba, K.; Kitagoh, H.; Miho, H.; Tomomatsu, H.; Yamaguchi, S.; Odani, M.; Yamamotoya, H. A randomized controlled phase II clinical trial comparing ONO-4053, a novel DP1 antagonist, with a leukotriene receptor antagonist pranlukast in patients with seasonal allergic rhinitis. Allergy 2017, 72, 1565-1575. [CrossRef]

148. Bianco, S.; Robuschi, M.; Grugni, A.; Ceserani, R.; Gandolfi, C. Effect of prostacyclin on antigen induced immediate bronchoconstriction in asthmatic patients. Prostaglandins Med. 1979, 3, 39-45. [CrossRef]

149. Liu, M.C.; Bleecker, E.R.; Lichtenstein, L.M.; Kagey-Sobotka, A.; Niv, Y.; McLemore, T.L.; Permutt, S.; Proud, D.; Hubbard, W.C. Evidence for elevated levels of histamine, prostaglandin D2, and other bronchoconstricting prostaglandins in the airways of subjects with mild asthma. Am. Rev. Respir. Dis. 1990, 142, 126-132. [CrossRef]

150. Liu, M.C.; Hubbard, W.C.; Proud, D.; Stealey, B.A.; Galli, S.J.; Kagey-Sobotka, A.; Bleecker, E.R.; Lichtenstein, L.M. Immediate and late inflammatory responses to ragweed antigen challenge of the peripheral airways in allergic asthmatics. Cellular, mediator, and permeability changes. Am. Rev. Respir. Dis. 1991, 144, 51-58. [CrossRef]

151. Fajt, M.L.; Gelhaus, S.L.; Freeman, B.; Uvalle, C.E.; Trudeau, J.B.; Holguin, F.; Wenzel, S.E. Prostaglandin D(2) pathway upregulation: Relation to asthma severity, control, and TH2 inflammation. J. Allergy Clin. Immunol. 2013, 131, 1504-1512. [CrossRef] [PubMed]

152. Pavord, I.D.; Ward, R.; Woltmann, G.; Wardlaw, A.J.; Sheller, J.R.; Dworski, R. Induced sputum eicosanoid concentrations in asthma. Am. J. Respir. Crit. Care Med. 1999, 160, 1905-1909. [CrossRef] [PubMed]

153. Marone, G.; Galdiero, M.R.; Pecoraro, A.; Pucino, V.; Criscuolo, G.; Triassi, M.; Varricchi, G. Prostaglandin D2 receptor antagonists in allergic disorders: Safety, efficacy, and future perspectives. Expert Opin. Investig. Drugs 2019, 28, 73-84. [CrossRef] [PubMed]

154. Wendell, S.G.; Fan, H.; Zhang, C. G Protein-Coupled Receptors in Asthma Therapy: Pharmacology and Drug Action. Pharmacol. Rev. 2020, 72, 1-49. [CrossRef] [PubMed]

155. Liu, W.; Min, J.; Jiang, H.; Mao, B. Chemoattractant receptor-homologous molecule expressed on Th2 cells (CRTH2) antagonists in asthma: A systematic review and meta-analysis protocol. Bmj Open 2018, 8, e020882. [CrossRef] [PubMed]

156. Murillo, J.C.; Dimov, V.; Gonzalez-Estrada, A. An evaluation of fevipiprant for the treatment of asthma: A promising new therapy? Expert Opin. Pharmacother. 2018, 19, 2087-2093. [CrossRef]

157. White, C.; Wright, A.; Brightling, C. Fevipiprant in the treatment of asthma. Expert Opin. Investig. Drugs 2018, 27, 199-207. [CrossRef]

158. Erpenbeck, V.J.; Popov, T.A.; Miller, D.; Weinstein, S.F.; Spector, S.; Magnusson, B.; Osuntokun, W.; Goldsmith, P.; Weiss, M.; Beier, J. Data on the oral CRTh2 antagonist QAW039 (fevipiprant) in patients with uncontrolled allergic asthma. Data Brief. 2016, 9, 199-205. [CrossRef]

159. Kao, C.C.; Parulekar, A.D. Spotlight on fevipiprant and its potential in the treatment of asthma: Evidence to date. J. Asthma Allergy 2019, 12, 1-5. [CrossRef]

160. Pelaia, C.; Crimi, C.; Vatrella, A.; Busceti, M.T.; Gaudio, A.; Garofalo, E.; Bruni, A.; Terracciano, R.; Pelaia, G. New treatments for asthma: From the pathogenic role of prostaglandin $\mathrm{d} 2$ to the therapeutic effects of fevipiprant. Pharmacol. Res. 2019, 155, 104490. [CrossRef]

161. Study of Efficacy and Safety of QAW039 in Patients with Severe Asthma Inadequately Controlled with Standard of Care Asthma Treatment. Available online: https://clinicaltrials.gov/ct2/show/NCT02555683 (accessed on 8 January 2020).

162. Study of Efficacy and Safety of QAW039 in Patients with Severe Asthma Inadequately Controlled with Standard of Care Asthma Treatment. Available online: https://clinicaltrials.gov/ct2/show/NCT02563067 (accessed on 8 January 2020).

163. Study of Efficacy and Safety of QAW039 When Added to Standard-of-Care Asthma Therapy in Patients with Uncontrolled Asthma. Available online: https:/clinicaltrials.gov/ct2/show/NCT03215758 (accessed on 8 January 2020). 
164. Study of Efficacy and Safety of QAW039 When Added to Standard-of-Care Asthma Therapy in Patients with Uncontrolled Asthma. Available online: https:/clinicaltrials.gov/ct2/show/NCT03226392 (accessed on 8 January 2020).

165. Asano, K.; Sagara, H.; Ichinose, M.; Hirata, M.; Nakajima, A.; Ortega, H.; Tohda, Y. A Phase 2a Study of DP2 antagonist GB001 for Asthma. J. Allergy Clin. Immunol. Pract. 2019. [CrossRef] [PubMed]

166. Langfang Xinghe Industry Co., Ltd. Study of the Tolerability and Pharmacokinetic of ZL-2102 with an Investigation of Food Effect in Healthy Male Subjects. Available online: https:/clinicaltrials.gov/ct2/show/ NCT02397005 (accessed on 8 January 2020).

167. Aggarwal, S.; Moodley, Y.P.; Thompson, P.J.; Misso, N.L. Prostaglandin E2 and cysteinyl leukotriene concentrations in sputum: Association with asthma severity and eosinophilic inflammation. Clin. Exp. Allergy J. Br. Soc. Allergy Clin. Immunol. 2010, 40, 85-93. [CrossRef]

168. Gauvreau, G.M.; Watson, R.M.; O'Byrne, P.M. Protective effects of inhaled PGE2 on allergen-induced airway responses and airway inflammation. Am. J. Respir. Crit. Care Med. 1999, 159, 31-36. [CrossRef] [PubMed]

169. Wasiak, W.; Szmidt, M. A six week double blind, placebo controlled, crossover study of the effect of misoprostol in the treatment of aspirin sensitive asthma. Thorax 1999, 54, 900-904. [CrossRef]

170. Mathe, A.A.; Hedqvist, P.; Holmgren, A.; Svanborg, N. Bronchial hyperreactivity to prostaglandin F 2 and histamine in patients with asthma. Br. Med. J. 1973, 1, 193-196. [CrossRef]

171. Kharitonov, S.A.; Sapienza, M.A.; Barnes, P.J.; Chung, K.F. Prostaglandins E2 and F2alpha reduce exhaled nitric oxide in normal and asthmatic subjects irrespective of airway caliber changes. Am. J. Respir. Crit. Care Med. 1998, 158, 1374-1378. [CrossRef]

172. Fujimura, M.; Ozawa, S.; Matsuda, T. Effect of oral administration of a prostacyclin analog (OP-41483) on pulmonary function and bronchial responsiveness in stable asthmatic subjects. J. Asthma 1991, 28, 419-424. [CrossRef]

173. Bianco, S.; Robuschi, M.; Ceserani, R.; Gandolfi, C. Effects of prostacyclin on aspecifically and specifically induced bronchoconstriction in asthmatic patients. Eur J. Respir. Dis. Suppl. 1980, 106, 81-87.

174. Hardy, C.C.; Bradding, P.; Robinson, C.; Holgate, S.T. Bronchoconstrictor and antibronchoconstrictor properties of inhaled prostacyclin in asthma. J. Appl. Physiol. (1985) 1988, 64, 1567-1574. [CrossRef]

175. Naclerio, R.M.; Creticos, P.S.; Norman, P.S.; Lichtenstein, L.M. Mediator release after nasal airway challenge with allergen. Am. Rev. Respir. Dis. 1986, 134, 1102. [CrossRef]

176. Shirasaki, H.; Kikuchi, M.; Kanaizumi, E.; Himi, T. Accumulation of CRTH2-positive leukocytes in human allergic nasal mucosa. Ann. Allergy Asthma Immunol. 2009, 102, 110-115. [CrossRef]

177. Ciebiada, M.; Gorski, P.; Antczak, A. Evaluation of eicosanoids in nasal lavage as biomarkers of inflammation in patients with allergic rhinitis. Arch. Med. Sci. 2014, 10, 1123-1128. [CrossRef] [PubMed]

178. Johnston, S.L.; Smith, S.; Harrison, J.; Ritter, W.; Howarth, P.H. The effect of BAY u 3405, a thromboxane receptor antagonist, on prostaglandin D2-induced nasal blockage. J. Allergy Clin. Immunol. 1993, 91, 903-909. [CrossRef]

179. Kajiwara, D.; Aoyagi, H.; Shigeno, K.; Togawa, M.; Tanaka, K.; Inagaki, N.; Miyoshi, K. Role of hematopoietic prostaglandin D synthase in biphasic nasal obstruction in guinea pig model of experimental allergic rhinitis. Eur. J. Pharm. 2011, 667, 389-395. [CrossRef]

180. Nabe, T.; Kuriyama, Y.; Mizutani, N.; Shibayama, S.; Hiromoto, A.; Fujii, M.; Tanaka, K.; Kohno, S. Inhibition of hematopoietic prostaglandin D synthase improves allergic nasal blockage in guinea pigs. Prostaglandins Other Lipid Mediat. 2011, 95, 27-34. [CrossRef]

181. Steinke, J.W.; Wilson, J.M. Aspirin-exacerbated respiratory disease: Pathophysiological insights and clinical advances. J. Asthma Allergy 2016, 9, 37-43. [CrossRef]

182. Li, K.L.; Lee, A.Y.; Abuzeid, W.M. Aspirin Exacerbated Respiratory Disease: Epidemiology, Pathophysiology, and Management. Med. Sci. 2019, 7, 45. [CrossRef]

183. Steinke, J.W.; Borish, L. Factors driving the aspirin exacerbated respiratory disease phenotype. Am. J. Rhinol. Allergy 2015, 29, 35-40. [CrossRef]

184. Parker, A.R.; Ayars, A.G.; Altman, M.C.; Henderson, W.R., Jr. Lipid Mediators in Aspirin-Exacerbated Respiratory Disease. Immunol. Allergy Clin. North. Am. 2016, 36, 749-763. [CrossRef]

185. Mastalerz, L.; Tyrak, K.E.; Ignacak, M.; Konduracka, E.; Mejza, F.; Cmiel, A.; Buczek, M.; Kot, A.; Oles, K.; Sanak, M. Prostaglandin E2 decrease in induced sputum of hypersensitive asthmatics during oral challenge with aspirin. Allergy 2019, 74, 922-932. [CrossRef] 
186. Adamusiak, A.M.; Stasikowska-Kanicka, O.; Lewandowska-Polak, A.; Danilewicz, M.; Wagrowska-Danilewicz, M.; Jankowski, A.; Kowalski, M.L.; Pawliczak, R. Expression of arachidonate metabolism enzymes and receptors in nasal polyps of aspirin-hypersensitive asthmatics. Int. Arch. Allergy Immunol. 2012, 157, 354-362. [CrossRef] [PubMed]

187. Machado-Carvalho, L.; Torres, R.; Perez-Gonzalez, M.; Alobid, I.; Mullol, J.; Pujols, L.; Roca-Ferrer, J.; Picado, C. Altered expression and signalling of EP2 receptor in nasal polyps of AERD patients: Role in inflammation and remodelling. Rhinology 2016, 54, 254-265. [CrossRef] [PubMed]

188. Walters, K.M.; Simon, R.A.; Woessner, K.M.; Wineinger, N.E.; White, A.A. Effect of misoprostol on patients with aspirin-exacerbated respiratory disease undergoing aspirin challenge and desensitization. Ann. Allergy Asthma Immunol. 2017, 119, 71-76. [CrossRef] [PubMed]

189. Cahill, K.N.; Bensko, J.C.; Boyce, J.A.; Laidlaw, T.M. Prostaglandin D(2): A dominant mediator of aspirin-exacerbated respiratory disease. J. Allergy Clin. Immunol. 2015, 135, 245-252. [CrossRef]

190. Szczeklik, A.; Sladek, K.; Dworski, R.; Nizankowska, E.; Soja, J.; Sheller, J.; Oates, J. Bronchial aspirin challenge causes specific eicosanoid response in aspirin-sensitive asthmatics. Am. J. Respir. Crit. Care Med. 1996, 154, 1608-1614. [CrossRef]

191. Rusznak, M.; Peebles, R.S., Jr. Prostaglandin E2 in NSAID-exacerbated respiratory disease: Protection against cysteinyl leukotrienes and group 2 innate lymphoid cells. Curr. Opin. Allergy Clin. Immunol. 2019, 19, 38-45. [CrossRef]

192. Bochenek, G.; Nagraba, K.; Nizankowska, E.; Szczeklik, A. A controlled study of 9alpha,11beta-PGF2 (a prostaglandin D2 metabolite) in plasma and urine of patients with bronchial asthma and healthy controls after aspirin challenge. J. Allergy Clin. Immunol. 2003, 111, 743-749. [CrossRef]

193. Nizankowska, E.; Czerniawska-Mysik, G.; Szczeklik, A. Lack of effect of i.v. prostacyclin on aspirin-induced asthma. Eur. J. Respir. Dis. 1986, 69, 363-368.

194. Xie, L.; Liu, A.G.; Cui, Y.H.; Zhang, Y.P.; Liao, B.; Li, N.N.; Wang, X.S. Expression profiles of prostaglandin E2 receptor subtypes in aspirin tolerant adult Chinese with chronic rhinosinusitis. Am. J. Rhinol. Allergy 2015, 29, 322-328. [CrossRef]

195. Perez-Novo, C.A.; Watelet, J.B.; Claeys, C.; Van Cauwenberge, P.; Bachert, C. Prostaglandin, leukotriene, and lipoxin balance in chronic rhinosinusitis with and without nasal polyposis. J. Allergy Clin. Immunol. 2005, 115, 1189-1196. [CrossRef]

196. Kim, J.H.; Choi, G.E.; Lee, B.J.; Kwon, S.W.; Lee, S.H.; Kim, H.S.; Jang, Y.J. Natural killer cells regulate eosinophilic inflammation in chronic rhinosinusitis. Sci. Rep. 2016, 6, 27615. [CrossRef] [PubMed]

197. Okano, M.; Fujiwara, T.; Yamamoto, M.; Sugata, Y.; Matsumoto, R.; Fukushima, K.; Yoshino, T.; Shimizu, K.; Eguchi, N.; Kiniwa, M.; et al. Role of prostaglandin D2 and E2 terminal synthases in chronic rhinosinusitis. Clin. Exp. Allergy J. Br. Soc. Allergy Clin. Immunol. 2006, 36, 1028-1038. [CrossRef] [PubMed]

198. Ying, S.; Meng, Q.; Scadding, G.; Parikh, A.; Corrigan, C.J.; Lee, T.H. Aspirin-sensitive rhinosinusitis is associated with reduced E-prostanoid 2 receptor expression on nasal mucosal inflammatory cells. J. Allergy Clin. Immunol. 2006, 117, 312-318. [CrossRef] [PubMed]

199. Machado-Carvalho, L.; Roca-Ferrer, J.; Picado, C. Prostaglandin E2 receptors in asthma and in chronic rhinosinusitis/nasal polyps with and without aspirin hypersensitivity. Respir. Res. 2014, 15, 100. [CrossRef]

200. Xie, L.; Liu, A.G.; Peng, L.Y.; Wang, S.J.; Zhang, Y.P.; Wang, X.S. Expression of E-prostanoid receptors in nasal polyp tissues of smoking and nonsmoking patients with chronic rhinosinusitis. PLOS ONE 2018, 13, e0200989. [CrossRef]

201. Yamamoto, M.; Okano, M.; Fujiwara, T.; Kariya, S.; Higaki, T.; Nagatsuka, H.; Tsujigiwa, H.; Yamada, M.; Yoshino, T.; Urade, Y.; et al. Expression and characterization of PGD2 receptors in chronic rhinosinusitis: Modulation of DP and CRTH2 by PGD2. Int. Arch. Allergy Immunol. 2009, 148, 127-136. [CrossRef]

(C) 2020 by the authors. Licensee MDPI, Basel, Switzerland. This article is an open access article distributed under the terms and conditions of the Creative Commons Attribution (CC BY) license (http://creativecommons.org/licenses/by/4.0/). 